\title{
MANCHESTER
}

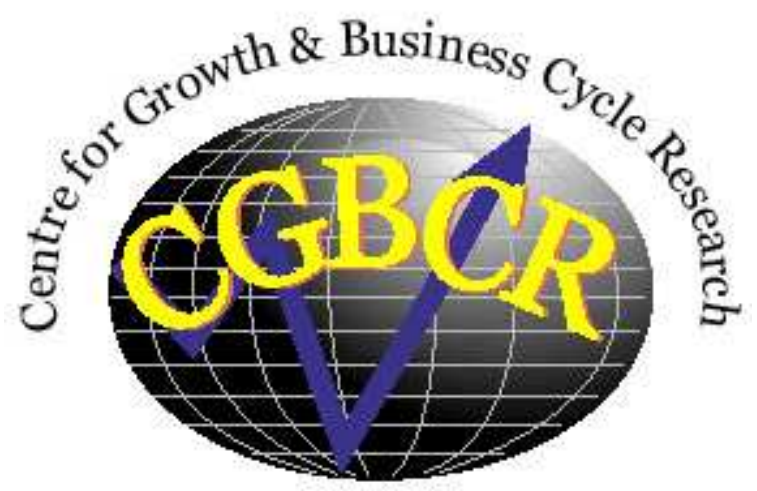

Discussion Paper Series

\section{Monetary Policy and Real Wage Cyclicality \\ By}

Amarasekara, C., and Bratsiotis, G.J.

Centre for Growth and Business Cycle Research, Economic Studies,

University of Manchester, Manchester, M13 9PL, UK

September 2009

Number 122

Download paper from:

http://www.socialsciences.manchester.ac.uk/cgbcr/discussionpape

rs/index.html 


\title{
Monetary Policy and Real Wage Cyclicality
}

\author{
Chandranath Amarasekara* and George J. Bratsiotis*† \\ This version: November 1, 2010.
}

\begin{abstract}
This paper points to the potential role of monetary policy in affecting the degree of real wage cyclicality. We show that the degree and direction of real wage cyclicality is determined by the interaction of (i) the returns to scale in production, (ii) the nature of aggregate shocks, and (iii) monetary policy. Given that production technology is fairly constant in the short run, we suggest that variations in the real wage - output covariance depend largely on the combination of the latter two. Identifying well-documeneted monetary policy phases in six major OECD countries and accounting for both aggregate demand and supply shocks, we provide empirical evidence to support our main theoretical claim.
\end{abstract}

JEL Classification Numbers: E24, E32, E52.

Keywords: Real wages; business cycles; real wage-output covariance; monetary policy; aggregate shocks.

*University of Manchester, United Kingdom, and Centre for Growth and Business Cycle Research.

${ }^{\dagger}$ Acknowledgements: I would like to thank Julian Messina and also Roger Farmer for useful comments on an early version of this paper. We also thank participants at a CGBCR workshop and other seminars for useful comments. Any errors and the views expressed in this paper remain ours. 


\section{Contents}

1 Introduction 3

2 The Model 6

2.1 Firms, Employment and Price and Wage Setting . . . . . . . . 8

2.2 Monetary Policy and Macro Equilibrium . . . . . . . . . . . 9

3 Aggregate Shocks, Monetary Policy and Real Wage Cyclicality $\mathbf{1 0}$

3.1 Demand Shocks, Monetary Policy and Real Wage Cyclicality . 11

3.2 Supply Shocks, Monetary Policy and Real Wage Cyclicality . . 12

4 Empirical Implications and Some Evidence 14

4.1 Australia . . . . . . . . . . . . . . . . 16

4.2 Canada . . . . . . . . . . . . . . . . 17

4.3 France . . . . . . . . . . . . . . . . . . 18

4.4 Germany . . . . . . . . . . . . . . . . . . 19

4.5 United Kingdom . . . . . . . . . . . . . . . . . 21

4.6 United States . . . . . . . . . . . . . . . . 22

5 Concluding Discussion $\quad 23$

6 References $\quad 26$

7 Appendix (Not for publishing) 44 


\section{Introduction}

Most empirical studies for the US indicate a weak real wage procyclicality which tends to rise in the post war period, a trend that is also observed in other OECD countries. This result however, has been shown to be very sensitive to the method, data, country and specific periods used to test the cyclicality of real wages (see Abraham and Haltiwanger 1995, Brandolini 1995). At the macro level, the literature seems to identify three main sources of real wage cyclicality, (i) the nature of aggregate shocks; (ii) the relative degree of nominal price and wage stickiness, and (iii) the type of production technology; or combinations of all three. In particular, a number of studies focus on the real wage cyclicality bias that may arise from the nature of aggregate shocks. They suggest that demand shocks lead to countercyclical real wages whereas supply shocks result in more procyclical real wages, but combinations of the two produce ambiguous results (Hoehn 1988, Bernanke and Carey 1996, Christiano, Eichenbaum and Evans 1997, Spencer 1998, Malley, Muscatelli and Woitek 2005). ${ }^{1}$ However, much of the literature also recognizes that the nature of shocks may not be the only factor determining real wage cyclicality. Some, for example, choose to focus on the relative degree of nominal price and wage rigidities, where traditionally a higher degree of nominal wage rigidity, relatively to price rigidity, implies a higher real wage countercyclicality during demand shocks, though results tend to be more ambiguous following a supply shock, (i.e. Huang and Liu 2002, Huang, Liu and Phaneuf 2004, Malley, Muscatelli and Woitek 2005); or on the role of various production technologies that affect the cyclicality of real wage (i.e.

\footnotetext{
${ }^{1} \mathrm{~A}$ few recent studies also examine the cost-side effects of aggregate demand. Barth and Ramey (2001), for example, show that through the effects of interest rates on the demand for capital, monetary policy affects both aggregate demand and aggregate supply and this may explain better the observed real wage - output correlation.
} 
Huang and Liu 2002, Huang, Liu and Phaneuf, 2004). ${ }^{2}$

In light of the evidence that real wage cyclicality tends to change over time, this paper points to the potential role of monetary policy as a determining source of such variations. Measuring real wage cyclicality by the contemporaneous covariance between the aggregate real wage and output (see Abraham and Haltiwanger 1995), we show that the type of monetary policy pursued by central banks can have important implications for real wage cyclicality. Such effects may be overlooked if monetary policy is assumed to be driven purely by exogenous monetary shocks. In order to divert from issues relating to the relative degrees of nominal rigidities, (already covered extensively in Huang, Liu and Phaneuf 2004 and Malley, Muscatelli and Woitek 2005), we use a simple wage setting rule that allows for the fact that nominal wages are stickier than prices. As we show below, this is sufficient to capture the well-documented evidence (see also above) that aggregate demand shocks are associated with countercyclical real wages whereas aggregate supply shocks are associated with procyclical real wages. Within this framework we show that aggregate shocks alone cannot provide the full explanation to the observed changes in real wage cyclicality. ${ }^{3}$ Instead, our theoretical

\footnotetext{
${ }^{2}$ This literature builds on the empirical evidence that returns to scale play a key role in the cyclicality of productivity (i.e. Basu and Fernald 1997, Basu, 1998, Kim and Kim 2006). Basu and Fernald (1997), for example, show that the output of durable-goods exhibit increasing returns to scale and this tends to make its output more procyclical than the average. Building on this finding, Huang Liu and Phaneuf (2004) suggest that changes in the cyclical behavior of real wages in the U.S. economy arise from the interactions of three sources, namely nominal wage and price rigidities and an evolving input-output structure.

${ }^{3}$ This is consistent with a number of recent studies that question the role of exogenous variations in technologies in explaining the postwar business cycle fluctuations, especially the labour market fluctuations (i.e. Basu, 1998, Basu and Taylor 1999, Galı 1999, Francis and Ramey 2002). Other studies show that exogenous monetary shocks alone have also not been able to overturn the real wage procyclicality observed during the post war period, (i.e. Christiano, Eichenbaum and Evans 1997, Barth and Ramey 2001).
} 
findings suggest that outside the obvious role of relative nominal frictions, the degree of real wage cyclicality is determined by the interaction of three sources: (i) the returns to scale in production, (ii) the nature of aggregate shocks, and (iii) monetary policy.

The first of these, returns to scale, appears to be an important determinant of the degree of real wage cyclicality in our theoretical model, but we expect the production technology to be fairly constant in the short run. ${ }^{4}$ This is consistent with the findings by Huang, Liu and Phaneuf (2004), that changes in the size of the elasticity of output with respect to their intermediate input are crucial for the direction of real wage cyclicality. ${ }^{5}$ Our results are also consistent with Basu and Fernald (1997) in that the assumption of increasing returns to scale can overturn the countercyclicality of real wage during demand shocks to real wage procyclicality. We thus accept that returns to scale matter for real wage cyclicality; however production technologies do not change in the short run, so there must be other factors that can account for variations in real wage cyclicality within shorter periods. This, we claim, can be explained by the nature of aggregate shocks and monetary policy. We show that following aggregate demand shocks tighter monetary policy with respect to either inflation or output gaps results in higher real wage procyclicality. However, under supply shocks whether monetary policy prioritizes inflation or output gaps matters for real wage cyclicality. This is because supply shocks force inflation and output to move in opposite directions, hence amplifying the importance of the monetary policy preferences.

\footnotetext{
${ }^{4}$ Brandolini, (1995) argues that empirically "there is no direct correspondence between the hypothesis of diminishing returns to labour and the cyclical pattern of the real wage as tests of the former have no necessary implication for the latter and vice versa".

${ }^{5}$ In their model that elasticity is modeled as an additional Cobb-Douglas elasticity entering the production function. This as we show below is very similar to the role of returns to scale, which is also very important for real wage cyclicality in our model.
} 
We show that in periods of supply shocks a higher (lower) relative weight on inflation, as opposed to output, results in higher (lower) real wage procyclicality. We provide some empirical support for our main theoretical results by examining the behavior of real wage cyclicality during distinct monetary policy phases in six major OECD countries (Australia, Canada, France, Germany, UK and the US), over the period 1960-2007.

The remainder of the paper is organized as follows. Section 2, derives our main theoretical framework. Section 3 examines the theoretical implications of the interaction of the returns to scale in production, the nature of aggregate shocks and the nature of monetary policy, for real wage cyclicality. Section 4 outlines the empirical implications and provides some evidence of our main theoretical findings. Section 5 discusses the main implications of the paper and concludes.

\section{The Model}

Consider an economy consisting of a continuum of imperfectly competitive firms, each producing a differentiated good, $j$, where $j \in(0,1)$. For simplicity let a representative household supply $N_{j}$ units of homogeneous labour to each

firm $j$, where $\int_{0}^{1} N_{j} d j=N_{t}$, is the total labour supply hours provided. The representative household maximizes expected lifetime utility,

$$
\begin{gathered}
\operatorname{Max} . E_{0} \sum_{s=0}^{\infty} \beta^{s} u\left(C_{t}, N_{t}\right) \\
u\left(C_{t}, N_{t}\right)=\frac{\sigma}{\sigma-1} C_{t}^{\frac{\sigma-1}{\sigma}}-\eta \frac{N_{t}^{1+\gamma}}{1+\gamma} \\
\text { where, } \quad C_{t}=\left(\int_{0}^{1} C_{j, t}^{(\theta-1) / \sigma} d j\right)^{\theta /(\theta-1)}, \quad \theta>1
\end{gathered}
$$




$$
P_{t}=\left(\int_{0}^{1} P_{j, t}^{(1-\theta)} d j\right)^{1 /(1-\theta)} .
$$

where, $\sigma, \gamma,>0$ are elasticities, $P_{t}$ is the aggregate price index of the household's consumption basket $C_{t}$ of all $C_{j, t}$ goods; $\theta$ is the elasticity of substitution between consumption goods. Cost minimization and assuming that in equilibrium, $C_{j}=Y_{j}$ results in,

$$
Y_{j, t}=\left(P_{j, t} / P_{t}\right)^{-\theta} Y_{t}
$$

Equation (4) is the conventional product demand of a differentiated good in a model with Dixit-Stiglitz preferences, where $Y_{t}$ is aggregate demand. The household maximizes utility subject to the following budget constraint,

$$
P_{t} C_{t}+M_{t}+B_{t}=W_{t} N_{t}+M_{t-1}+R_{t-1} B_{t-1}+V_{t}+T_{t}
$$

where $W, B_{t}, B_{t-1}, M_{t}, M_{t-1}, V_{t}=\int_{0}^{1} V_{j, t} d j$, and $T_{t}$ are respectively, the average nominal wage, the desired and initial bond and money holdings, nominal profits of all firm $j$ and transfers; $R_{t}=\left(1+i_{t}\right)$ is the gross interest payment to government bond holders, where for simplicity $i_{t}$ is the risk-free refinance rate.

From the household's maximization problem, the first order conditions are,

$$
\begin{gathered}
C_{t}=E_{t}\left(\beta C_{t+1}^{-(1 / \sigma)} \frac{R_{t}}{1+\pi_{t+1}}\right)^{-\sigma} \\
W_{t}^{*}=P_{t} C_{t}^{(1 / \sigma)} \eta N_{t}^{\gamma}
\end{gathered}
$$

Equation (6) is a standard Euler equation, whereas equation (7) shows the equilibrium wage is determined by the the aggregate price level and the marginal rate of substitution between leisure and consumption, as shown elsewhere in the literature. 


\subsection{Firms, Employment and Price and Wage Setting}

The technology of firm $j$ is driven by the input of labour $j$,

$$
Y_{j, t}=Z_{t} N_{j, t}^{\alpha}
$$

where, $Z_{t}$ is i.i.d and a scalar comprising all productivity factors and $\alpha \lesseqgtr 1$ describes the returns to scale. In each period $t$ the maximization problem of firm $j$ is,

$$
\max \cdot V_{j, t}=P_{j, t} Y_{j, t}-W_{j, t} N_{j, t} .
$$

Using (4), (8) and (9), the optimal price of firm $j$ is derived as a mark-up over marginal cost,

$$
P_{j, t}=\mu_{j} W_{j, t} N_{j, t}^{1-\alpha} / \alpha Z_{t}
$$

where $\mu_{j}=\theta /(\theta-1)>1$ is the fixed price mark-up. Using (8) into (10), aggregating over symmetric firms and log-linearizing, the aggregate price is,

$$
p_{t}=w_{t}+\alpha^{-1}(1-\alpha) y_{t}-z_{t} / \alpha
$$

If both prices and wages were fully flexible, then there would be no role for monetary policy. In order to provide some scope for monetary policy, while keeping our results consistent with those of the rest of the literature that capture the fact that nominal wages are stickier than prices, we employ the following wage-setting rule,

$$
W_{j, t}=E_{t-1} W_{t}^{*}
$$

This simple and widely used wage-setting rule assumes that wages are predetermined one period in advance, based on the expected (at time $t-1$ ) optimal wage for period $t$ (see Fischer 1977, or more recently, Dixon and Kara 2010). Using (7) into (12) and averaging across symmetric wages (i.e. 
where all labor market employs one-period predetermined wages) results in the following log-linearized average wage,

$$
w_{t}=E_{t-1}\left(p_{t}+\frac{\alpha+\gamma \sigma}{\alpha \sigma} y_{t}-\frac{\gamma}{\alpha} z_{t}\right)
$$

Hence, if $z_{t}$ follows a white noise, the expected real wage is purely a function of output (or employment), as expected in the related literature (see Abraham and Haltiwanger 1995, Spencer 1998, Walsh 2003, Dixon and Kara 2010 , etc).

\subsection{Monetary Policy and Macro Equilibrium}

From the log-linearization of (6), and using the goods market equilibrium condition, $C_{t}=Y_{t}$, aggregate demand is,

$$
y_{t}=E_{t} y_{t+1}-\sigma\left(i_{t}-E_{t} \pi_{t+1}\right)
$$

We assume that monetary policy is concerned with inflation and output stability and it is conducted through a standard Taylor-type interest rate rule,

$$
i_{t}=\phi_{\pi}\left(\pi_{t}-\pi^{*}\right)+\phi_{y} y_{t}+d_{t}
$$

where, $\pi^{*}$ is a desired rate of inflation and $d_{t}$ is an i.i.d. demand shock. Substituting equation (15) in (14), aggregate demand becomes

$$
y_{t}=\frac{E_{t} y_{t+1}+\sigma E_{t} \pi_{t+1}-\sigma \phi_{\pi}\left(\pi_{t}-\pi^{*}\right)-\sigma d_{t}}{1+\sigma \phi_{y}}
$$

Substituting (16) into (13) and (11) and solving for the rational expectations equilibrium we obtain the reduced forms of output, $y_{t}$ and the real wage, $\omega_{t} \equiv w_{t}-p_{t}{ }^{6}$

$$
y_{t}=-\frac{\alpha \sigma}{\alpha\left(1+\sigma \phi_{y}\right)+(1-\alpha) \sigma \phi_{\pi}} d_{t}+\frac{\sigma \phi_{\pi}}{\alpha\left(1+\sigma \phi_{y}\right)+(1-\alpha) \sigma \phi_{\pi}} z_{t}
$$

\footnotetext{
${ }^{6}$ For the detailed solution see Appendix A
} 


$$
\omega_{t}=\frac{(1-\alpha) \sigma}{\alpha\left(1+\sigma \phi_{y}\right)+(1-\alpha) \sigma \phi_{\pi}} d_{t}+\frac{1+\sigma \phi_{y}}{\alpha\left(1+\sigma \phi_{y}\right)+(1-\alpha) \sigma \phi_{\pi}} z_{t}
$$

Equations (17) and (18) confirm the familiar result that with flexible nominal variables and rational expectations only stochastic shocks affect real variables at the macro equilibrium. In addition, the policy parameters of systematic monetary policy also affect the response of real variables to demand and supply shocks. Note that in this standard macro framework with i.i.d. processes, constant returns to scale, $(\alpha=1)$, imply that only supply shocks affect real wages, whereas the assumption of exogenous monetary policy, $\phi_{\pi}=\phi_{y}=0$, results in output being purely aggregate demand driven (i.e. through the Euler equation). ${ }^{7}$

\section{Aggregate Shocks, Monetary Policy and Real Wage Cyclicality}

Using equations (17) and (18) and the assumption that both supply (z) and demand shocks $(d)$ are i.i.d processes, and $\operatorname{Cov}(d, z)=0$, we derive the real wage - output covariance,

$$
\begin{aligned}
\operatorname{Cov}_{(\omega, y)}= & -\frac{(1-\alpha) \alpha \sigma^{2}}{\left(\alpha\left(1+\sigma \phi_{y}\right)+(1-\alpha) \sigma \phi_{\pi}\right)^{2}} \operatorname{Var}_{(d)} \\
& +\frac{\left(1+\sigma \phi_{y}\right) \sigma \phi_{\pi}}{\left(\alpha\left(1+\sigma \phi_{y}\right)+(1-\alpha) \sigma \phi_{\pi}\right)^{2}} \operatorname{Var}_{(z)} .
\end{aligned}
$$

Real wage cyclicality, as indicated by the real wage - output covariance (as in Abraham and Haltiwanger, 1995), is shown to depend here mainly on,

\footnotetext{
${ }^{7}$ The latter effect is true because in models with a forward looking aggregate demand, supply shocks affect aggregate output mainly through autoregressive shocks to future output and expected inflation and also through the interest policy rule that responds to equilibrium output and inflation conditions. Hence with i.i.d. shocks (i.e. in the absence of autoregressive shocks), and no interest rate responses to output and inflation, the (contemporaneous) equilibrium output is free of supply shocks.
} 
(i) the returns to scale $(\alpha)$, (ii) the nature of the shock $\left(d_{t}, z_{t}\right)$ and (iii) the monetary policy parameters $\left(\phi_{\pi}, \phi_{y}\right)$.

\subsection{Demand Shocks, Monetary Policy and Real Wage Cyclicality}

As indicated elsewhere in the literature other things kept constant demand shocks usually generate countercyclical real wages (see Abraham and Haltiwanger, 1995). In particular, considering only demand shocks and decreasing returns, $\alpha<1$, we obtain,

$$
\left[\operatorname{Cov}_{(\omega, y)}\right]_{z_{t}=0}=-\frac{(1-\alpha) \alpha \sigma^{2}}{\left(\alpha\left(1+\sigma \phi_{y}\right)+(1-\alpha) \sigma \phi_{\pi}\right)^{2}} \operatorname{Var}_{(d)}<0
$$

and hence during demand shocks real wages are countercyclical, but here the degree of countercyclicality depends also on the monetary policy parameters, as follows,

$$
\begin{aligned}
& \qquad\left[\frac{\partial \operatorname{Cov}_{(\omega, y)}}{\partial \phi_{\pi}}\right]_{z_{t}=0}=\frac{2 \alpha(1-\alpha)^{2} \sigma^{3}}{\left(\alpha\left(1+\sigma \phi_{y}\right)+(1-\alpha) \sigma \phi_{\pi}\right)^{3}}>0, \\
& \text { and }\left[\frac{\partial \operatorname{Cov}_{(\omega, y)}}{\partial \phi_{y}}\right]_{z_{t}=0}=\frac{2 \alpha^{2}(1-\alpha) \sigma^{3}}{\left(\alpha\left(1+\sigma \phi_{y}\right)+(1-\alpha) \sigma \phi_{\pi}\right)^{3}}>0,
\end{aligned}
$$

In this transparent framework, what determines whether inflation or output stabilization policies imply a higher real wage countercyclicality, depends purely on the value of returns to scale $(\alpha)$, which here also determine the direction of cyclicality. For any value of $\alpha<1$ real wages are countercyclical, whereas with increasing returns to scale $\alpha>1$ real wage becomes procyclical and the results (under demand shocks) are reversed. ${ }^{8}$ Assuming, $\alpha<1$, as our benchmark case, demand shocks are shown to imply real wage countercyclicality regardless of whether we consider exogenous monetary policy,

\footnotetext{
${ }^{8}$ This is consistent with the findings of Basu and Fernald (1997)
} 
$\phi_{\pi}=\phi_{y}=0$, or endogenous monetary policy, $\phi_{\pi}, \phi_{y}>0$. However, in this case (i.e. with $\alpha<1$ ) during demand shocks active stabilization monetary policy (positive values of $\phi_{\pi}$ or $\phi_{y}$ ) makes real wages less countercyclical than exogenous monetary policy, as it is obvious from (20) when $\phi_{y}=\phi_{\pi}=0$ for the latter case.

In general, because during demand shocks inflation and output move in the same direction, monetary policy that focuses on either inflation or output stability has similar effects on the degree of real wage cyclicality, namely they reduce real wage coutercyclicality. Under demand shocks therefore, monetary policy preferences over these two aggregates may not be as important for the cyclicality of real wages as under supply shocks, where as we show below policy preferences become more crucial.

\subsection{Supply Shocks, Monetary Policy and Real Wage Cyclicality}

The bulk of the literature has also indicated that other things kept constant supply shocks generate procyclical real wages. ${ }^{9}$ This is confirmed from (19) which keeping other shocks equal to zero implies,

$$
\left[\operatorname{Cov}_{(\omega, y)}\right]_{d_{t}=0}=\frac{\sigma \phi_{\pi}\left(1+\sigma \phi_{y}\right)}{\left(\alpha\left(1+\sigma \phi_{y}\right)+(1-\alpha) \sigma \phi_{\pi}\right)^{2}} \operatorname{Var}_{(z)}>0
$$

In general, as (22) shows, supply shocks imply procyclical real wages, but the degree of real wage procyclicality is shown here to be crucially determined by the monetary policy parameters in combination with returns to scale. In particular,

$$
\left[\frac{\partial \operatorname{Cov}_{(\omega, y)}}{\partial \phi_{\pi}}\right]_{d_{t}=0}=\frac{\sigma\left(1+\sigma \phi_{y}\right)\left(\alpha\left(1+\sigma \phi_{y}\right)-(1-\alpha) \sigma \phi_{\pi}\right)}{\left(\alpha\left(1+\sigma \phi_{y}\right)+(1-\alpha) \sigma \phi_{\pi}\right)^{3}}
$$

\footnotetext{
${ }^{9}$ See the thorough literature review in Abraham and Haltiwanger (1995).
} 


$$
\text { and }\left[\frac{\partial \operatorname{Cov}_{(\omega, y)}}{\partial \phi_{y}}\right]_{d_{t}=0}=-\frac{\sigma^{2} \phi_{\pi}\left(\alpha\left(1+\sigma \phi_{y}\right)-(1-\alpha) \sigma \phi_{\pi}\right)}{\left(\alpha\left(1+\sigma \phi_{y}\right)+(1-\alpha) \sigma \phi_{\pi}\right)^{3}} \text {. }
$$

In the benchmark case of exogenous monetary policy, $\phi_{\pi}=\phi_{y}=0$, output is driven purely by aggregate demand, (see 17), and so under exogenous monetary policy real wages are acyclical, $\left[\operatorname{Cov}_{(\omega, y)}\right]_{d_{t}=0}=0$. However, during supply shocks endogenous monetary policy, and particularly whether monetary policy places a larger weight on inflation or output stability appears to be non-trivial for the degree of real wage cyclicality. A higher relative weight on inflation stability increases the degree of real wage cyclicality, whereas the opposite is true for a higher relative weight on the output gap, which reduces real wage cyclicality during supply shocks. This can be formally shown from (22), where with constant returns to scale, $(\alpha=1), \frac{\partial \operatorname{Cov}_{(\omega, y)}}{\partial \phi_{\pi}}=\frac{\sigma}{1+\sigma \phi_{y}}>0$, whereas $\frac{\partial \operatorname{Cov}_{(\omega, y)}}{\partial \phi_{y}}=-\frac{\sigma^{2} \phi_{\pi}}{\left(1+\sigma \phi_{y}\right)^{2}}<0$.

\section{\{Fig. 1\} \{Fig. 2\}}

Relaxing the assumption of constant returns makes real wage cyclicality more sensitive to the values of the monetary policy parameters. Figures 1 and 2 compare the impact of monetary policy on real wage cyclicality, under supply shocks and for different values of the policy parameters and returns to scale. In these examples we restrict both policy parameters to be positive, $\left(\phi_{\pi}, \phi_{y}>\right.$ $0)$, and $\operatorname{Cov}_{(\omega, y)}$ to lie between zero and unity. Given this, any $\phi_{\pi}$ that satisfies the condition, $0<\phi_{\pi}<\frac{1+\sigma \phi_{y}}{\sigma}$, implies that real wage procyclicality increases in $\phi_{\pi}$, whereas any value of $\phi_{y}$ that satisfies the condition $0<\frac{\sigma \phi_{\pi}-1}{\sigma}<\phi_{y}$ implies that real wage procyclicality decreases in $\phi_{y}$. Overall, the case of increasing returns, $\alpha>1$, provides amplified results as shown in Figures 1 
and $2 .^{10}$

In general, because during supply shocks inflation and output are likely to move in the opposite direction, the choice of whether to stabilize inflation or output can have non-negligible implications for real wage cyclicality. During supply shocks a higher weight on inflation stability magnifies the degree of real wage procyclicality whereas a higher weight on output stability has the opposite effect, unless returns to scale are very low. Further, any value of $\phi_{\pi}>0$ implies real wage procyclicality levels higher than those implied by exogenous monetary policy (which implies real wage acyclicality here). Conversely, higher relative weights on output stability, $\phi_{y}>0$, reduce real wage procyclicality, though other things kept constant, it is only at its extreme value of $\phi_{y} \rightarrow \infty$, (where output variations are eliminated), that real wage cyclicality approaches the exogenous monetary policy outcome, $\left[\operatorname{Cov}_{(\omega, y)}\right]_{d_{t}=0}=0$.

\section{Empirical Implications and Some Evidence}

The above analysis suggests that even in the absence of notable labour market changes, the cyclicality of real wages may be changing over time in response to changes in monetary policy and the nature of aggregate shocks. Interest rates may be changing in response to nominal or real variables or both and as the theory suggests whether monetary policy places more emphasis on inflation or output can have very different implications for the real wage output correlation, particularly in times of supply shocks where inflation and output are forced into opposite directions.

\footnotetext{
${ }^{10}$ Note that for any value of $\alpha$, endogenous monetary policy still implies a higher real wage cyclicality than exogenous monetary policy (which here implies $\left[\operatorname{Cov}_{(\omega, y)}\right]_{d_{t}=0}=0$ )
} 
In this section we provide some empirical evidence to support our view that monetary policy that places a relatively higher weight on inflation, as opposed to output, tends to raise real wage procyclicality. As suggested by the theoretical model, this is particularly true during supply shocks and periods of strong anti-inflation policy. In particular, from (15) and (16), the higher is the inflation gap that the central bank tries to stabilize (i.e. $\left.\pi_{t}-\pi^{*}\right)$ and the more concerned is the monetary authority with inflation (i.e. the higher is $\phi_{\pi}$, in relation to $\phi_{y}$ ), the higher should be the observed real wage procyclicality. Conversely, in periods of relatively low and stable inflation, where the inflation gap from desired inflation is very small, the role of $\phi_{\pi}$ becomes less significant and so does its expected effect on real wage cyclicality.

We use well-documented evidence to identify distinct monetary policy phases for each of the six OECD countries we examine. Then accounting for the nature of aggregate shocks, we examine the degree of real wage cyclicality during these monetary policy phases. ${ }^{11}$ Real wage cyclicality is measured by the real wage - output correlation, (see Abraham and Haltiwanger, 1995). Because, as shown by the theoretical model, both monetary policy and the nature of aggregate shocks matter for real wage cyclicality, we use two different methods of accounting separately for the effects of the aggregate shocks on real wage cyclicality. ${ }^{12}$ First, we use a dummy variable for the episodes

\footnotetext{
${ }^{11}$ Note that in identifying anti-inflation periods we are not concerned whether these are implemented via monetary targets as in the earlier periods or interest rates and inflation targeting as in most recent years. Bratsiotis (2007) shows that both monetary and interest rate policy rules produce very similar contemporaneous correlations between real prices and output, although the two may have different implications for the dynamic behavior of macro variables.

${ }^{12}$ Aggregate supply and demand shocks are likely to be frequently serially correlated. However, the assumption here is that we are mainly concerned with periods when one type of shock (i.e. supply or demand) is more dominant. This is the purpose of testing for aggregate demand and supply shock periods using two different methods.
} 
identified by Blanchard and Galí (2007) as oil shock periods. GMM estimates for real wage cyclicality using this dummy variable are shown in panels (A) in the ensuing tables. The second method we use is based on the behavior of prices and consumption in the international crude oil market. Observing both prices and consumption patterns allows us to identify whether shocks are caused by demand side or supply side factors. Real wage cyclicality estimates using this method of accounting for the nature of aggregate shocks are shown in panels (B) in the tables below. ${ }^{13}$ Note that our results are robust to the empirical method used. Replicating the same tests using the OLS method produces very similar results to our GMM estimates. ${ }^{14}$

\subsection{Australia}

Since the early 1960's, Australia's first phase of a higher relative emphasis on inflation was in 1976Q1 when monetary targets were announced to combat the fast rising inflation in the mid 1970's. Monetary targets were abandoned and monetary policy was relaxed again in January 1985 (see Grenville 1997, Macfarlane 1999). The period that followed experienced overall lower inflation rates and the Australian monetary authority experimented with a number of monetary targeting and multiple indicator targeting, (see Argy, Brennan and Stevens 1990, Brischetto and Voss 1999 and Macfarlane 1999). The Reserve Bank of Australia defined price stability again as the ultimate target of monetary policy and adopted inflation targeting in 1993Q2 (see Grenville 1997, Gerlach and Smets 2000, Ball and Sheridan 2005). We thus examine Australian data within the following periods: (I) 1964Q3-1975Q4: Pre-antiinflation period; (II) 1976Q1-1985Q1: Anti-inflation period; (III) 1985Q2-

\footnotetext{
${ }^{13}$ For details of this method see Appendix B.

${ }^{14}$ The OLS estimates are shown in Appendix D.
} 
1993Q1: Various monetary policy experiments; (IV) 1993Q2-2000Q4: Disinflation phase under inflation targeting; (V) 2001Q1-2004Q4: Period of relatively low and stable inflation.

[Table 1: GMM Estimates of the Cyclicality of Real Wages - Australia] Table 1 shows that real wage procyclicality is much higher during the antiinflation in periods II and IV, compared with the other three periods; this is true regardless of the method used to account for the effects of aggregate shocks.

\subsection{Canada}

In October 1975, following double-digit inflation figures in 1973 and 1974, the Bank of Canada announced an anti-inflation program (AIP) which also included targets for price inflation (see Sargent 2005). The anti-inflation program lasted until mid 1978 when the Bank of Canada began to distance itself from this strategy (see Bernanke and Mishkin 1992 and Sargent 2005). The policy that followed was initially monetary targeting to boost the depreciating exchange rate until 1982 and then a relative higher emphasis on output and employment to assist the economy out of the recession that had begun in 1981. In January 1988, Governor John Crow announced an objective of "price stability" and elimination of inflation (see Bernanke and Mishkin 1992, Debelle 1996, Laidler 1999, Miles 2008). In February 1991, the Bank and the Minister of Finance jointly announced a series of declining inflation targets but shortly after the introduction of inflation targeting the inflation rate stabilized at around 2 per cent. (see above literature and Gerlach and Smets 2000, González-Hermosillo and Ito 1997 and Dodge 2002). Based on 
this we examine Canadian data within the following periods: (I) 1963Q11975Q2: Pre-anti-inflation period; (II) 1975Q3-1978Q2: Anti-inflation program (AIP); (III) 1978Q3-1987Q4: Mixed strategies to support depreciating exchange rate; (IV) 1988Q1-1991Q1: Commitment to price stability and to eliminate inflation; (V) 1991Q2-2004Q4: Formal adoption of inflation targeting but also period of relatively low and stable inflation.

[Table 2: GMM Estimates of the Cyclicality of Real Wages - Canada]

As shown in Table 2, real wages in Canada tend to be in general countercyclical. They only become strongly procyclical during the strong anti-inflation program (period II), then they turn countercyclical again, with acyclical real wages during the commitment to inflation stability (Period IV). Countercyclical real wages for Canada are also shown by other studies that use aggregate real wage data, including Messina, Strozzi and Turunen (2009) for the period $1960-2004 .^{15}$

\subsection{France}

With the view to achieving exchange rate and monetary stability France joined the Exchange Rate Mechanism (ERM) in March 1979, but its inflation experience shows that France was not successful in reducing inflation under the ERM (see Smets 1997), thus a stricter anti-inflation policy followed in 1983. According to Artus, Aronyi-Dovi, Blenze and Lecointe (1991),

\footnotetext{
${ }^{15}$ However, studies that use micro data suggest procyclical real wages for Canada. Liu (2003), for example, shows that Canada produces procyclical real wages though the degree of the latter tends to be weaker to that of the US and the UK. Similar evidence is provided by other studies that emphasize the compositional workforce bias. Castro and Coen-Pirani (2008), for example, argue that if labour force quality is countercyclical then aggregate hours of work is likely to introduce a countercyclical bias in the measure of the real wage and make employment of skilled labour more procyclical. For alterantive exaplanations see also Farès and Lemieux, (2001) and Sharpe, Arsenault and Harrison (2008).
} 
and Clarida, Galí, and Gertler (1998), May 1983 marks the "time of the U-turn away from state largesse" and directing monetary policy against inflation (see also Argy, Brennan, and Stevens, 1990). Inflation was brought under control by the end 1985 and for the first time since mid 1960s inflation dropped below 2 percent in 1986Q1 (Clarida, Galí, and Gertler, 1998, Bilke 2005). France maintained inflation at low levels since then through various measures including the pegging of its currency to the Deutsche Mark. Accordingly, the periods we consider for France are: (I) 1963Q1-1979Q1: Pre-anti-inflation period; (II) 1979Q2-1983Q1: Attempts to achieve inflation stability under ERM; (III) 1983Q2-1985Q4: Strong anti-inflation period; (IV); 1986Q1-1998Q4: Pre-Euro period of relatively low and stable inflation; and (V) 1999Q1-2004Q4: Post-Euro period with relatively low and stable inflation.

[Table 3: GMM Estimates of the Cyclicality of Real Wages - France]

Table 3 displays that during the anti-inflation periods (II and III), real wages are highly procyclical. Note that despite the rather unsuccessful disinflation during period II, where France attempted to achieve inflation stability by joining the ERM, highly procyclical real wages can still be observed. During periods I, IV and V, real wages have remained mildly countercyclical or acyclical.

\subsection{Germany}

Germany's entry into the European Monetary System (EMS) in March 1979 is considered by many as a major phase in its monetary policy (see Smets 1997, Clarida, Galí, and Gertler 1998, Gerberding, Seitz, Worms 2005, and 
Senda 2005). The Bundesbank's commitment to fight inflation waned somewhat during the period between the two major oil shocks (Clarida and Gertler 1996), however as Clarida, Galí, and Gertler (1998) report, in March 1979 "controlling inflation became a major focus of monetary policy" for the Bundesbank. Commenting on the period between 1983-1989, Clarida and Gertler (1996) observe that inflation was below target and the real economy was weak and the Bundesbank was "prompted to demonstrate its flexibility in both actions and language" and ease short term rates in order to support economic recovery. The annual inflation projection had been steady at 2 per cent since 1984, and inflation had been at low levels since then apart from a blip following the reunification of Germany (see Argy, Brennan and Stevens, 1990, Bernanke and Mihov, 1997, and Gerberding, Seitz, and Worms, 2005). During the reunification process, "to prevent potential inflationary consequences the Bundesbank adopted a tight monetary policy by raising German interest rate repeatedly between 1990 and 1993" (Weber, 1996). In fact, policy interest rates continued to be raised since June 1989 and only in September 1992 the Bundesbank started easing monetary policy. Given the above, we consider the following periods for Germany: (I) 1963Q1-1979Q1: Pre-anti-inflation period; (II) 1979q2-1983Q4: Strong anti-inflation period; (III) 1984Q1-1989Q2: Low inflation period prior to German reunification and more emphasis on output stability; (IV) 1989Q3-1992Q3: Anti-inflation policy following reunification; (V) 1992Q4-1998Q4: Pre-Euro period of relatively low and stable inflation; (VI) 1999Q1-2004Q4: Post-Euro period with relatively low and stable inflation.

[Table 4: GMM Estimates of the Cyclicality of Real Wages - Germany] As seen in Table 4, during the strong anti-inflation phases (periods II and 
IV), real wages in Germany become significantly more procyclical in relation to all other periods. Note also that period III exhibits countercyclicality. This effect is also consistent with the theoretical implications of the paper since policy emphasis during that period in Germany was switched to output stability (see Clarida and Gertler 1996).

\subsection{United Kingdom}

In the UK, the formation of the Conservative government under Prime Minister Thatcher in June 1979 is considered to be a major turning point where fighting inflation became a clear policy objective, (Bernanke and Mishkin, 1992, Bowen, 1995, Clarida, Galí and Gertler, 1998, Bernanke, et al. 1999, Nelson, 2000). In the period 1987 to 1990, the UK entered a second stage of strict monetary policy that informally linked the Pound to the Deutsche Mark and was characterized by high real interest rates, (see Bowen, 1995, King, 1997 and Nelson, 2000). In October 1992, following its departure from the ERM, the UK formally adopted inflation targeting. The Bank of England became independent in May 1997, further enhancing its focus on price stability. However, as with most of the industrial countries, the decade that follows is characterized by low and stable inflation. In what follows for the UK data we use Nelson's (2000) monetary policy periods: (I) 1966Q1-1979Q2: PreThatcher period; (II) 1979Q3-1987Q1: Thatcher era and first stage of tight monetary (anti-inflation) policy; (III) 1987Q2-1992Q3: Second stage of tight monetary policy to keep Sterling Pound in line with the Deutsche Mark and pave the way to inflation targeting; (IV) 1992Q4-2004Q4: Formal adoption of inflation targeting but also a period of relatively low and stable inflation. ${ }^{16}$

\footnotetext{
${ }^{16}$ In fact, Nelson (2000) skips the period 1990-1992; also his sample ends in 1997.
} 
[Table 5: GMM Estimates of the Cyclicality of Real Wages - UK]

As shown in Table 7 , in the UK real wages are substantially more procyclical in the two periods of contractionary monetary policy (periods II and III) rather than in the pre-Thatcher years and the relatively low and stable inflation period (periods I and IV respectively).

\subsection{United States}

Clarida, Galí and Gertler (1999) argue that prior to 1979 the Federal Reserve "tended to accommodate rather than fight increased expected inflation". Similarly, Romer and Romer (1989) show that "after several years of expressing concern about inflation but taking little concrete action to combat it, Federal Reserve policy changed significantly in 1978", when steps to tighten policy and combat inflation began in August 1978, (see Friedman and Friedman 1984 and Nelson 2004). Yet, after "deciding that its measures over the previous year had been unsuccessful in reducing inflation and that much stronger measures were needed", the Federal Reserve announced active anti-inflation policy in October 1979. There appears to be a general consensus that Chairman Volcker's announcement of active anti-inflation policy marks the beginning of a new phase in the US monetary policy with strong emphasis on price stability (see Bernanke and Mishkin, 1992, Judd and Trehan, 1995, Mehra, 1997, 1999, Judd and Rudebusch, 1998, Clarida, Galí, and Gertler, 1998, 2000, Taylor, 1999, Bordo and Schwartz, 1999, Favero and Rovelli, 2003, Senda, 2005, and Goodfriend, 2005, among others). By 1982 quarterly inflation had reduced to a low level and "a deepening business recession with unemployment at record levels" prompted "a temporary abandonment" of tight monetary policy (Friedman, 1984), but the overall 
focus on price stability was maintained. In August 1987, when Greenspan took office, he pledged to keep inflation low and increase consumer confidence in the economy. The periods, therefore we consider for the US are: (I) 1963Q1-1978Q2: Pre-anti-inflation period; (II) 1978Q3-1981Q4: Strong anti-inflation period including the period following Volcker's initial policy announcement; (III) 1982Q1-2004Q4: Low inflation and the period of "effective price stability" according to Greenspan (see Goodfriend, 2005).

[Table 6: GMM Estimates of the Cyclicality of Real Wages - US]

The results in Table 8 suggest that regardless of the method capturing the effects of aggregate shocks, real wages are shown to be substantially more procyclical during period II, than the other periods. As with most of the other countries we examine, and consistent with our theoretical implications, real wage procyclicality eases (or becomes statistically insignificant) in periods of relatively low and stable inflation, (column III here).

\section{Concluding Discussion}

Real wage cyclicality is too variant in the short run to be explained purely by changes in the structural parameters on the supply side of the economy, such as production technology and returns to scale. In this paper we show that outside the well-established role of relative nominal price and wage rigidities and changes in technology, the degree of real wage cyclicality is also deter-

mined by the interaction of two sources: the nature of aggregate shocks and monetary policy responses. We show that aggregate demand shocks tend to generate real wage coutercyclicality, but more active stabilization policy in periods of demand shocks reduces real wage coutercyclicality. Aggregate 
supply shocks tend to generate real wage procyclicality, but as this type of shock forces inflation and output to move in opposite directions, preferences in systematic monetary policy matter for the effects on real wage cyclicality. A higher relative weight on inflation exacerbates the increase in real wage procyclicality. The latter effect is shown to be stronger the higher is the inflation stabilization gap or in high inflation periods. Conversely, real wage cyclicality falls if the monetary authority is more concerned with output gaps or in periods of relatively low and stable inflation.

The empirical evidence we provide, from six major OECD countries, seems to be consistent with our main theoretical claim. In particular, after accounting for the potential effects of aggregate shocks on real wage cyclicality, we show that in times of anti-inflation policy, the observed real wage procyclicality increases, whereas in periods of output-focused policy real wage cyclicality falls. In periods of relatively high inflation stability or small inflation gaps from desired or target levels (i.e. for most of 1990's), the effects of monetary policy on real wage cyclicality become less significant; this is true even when inflation stability remains the monetary authority's main policy objective.

Our results appear to be consistent with a number of other results shown in the literature. For example, Basu and Taylor (1999), indicate that the correlation between real wages and aggregate output in the U.S. economy has changed from -0.444 in the interwar period (1919-1939), to 0.381 during the Bretton Woods period (1945-1971), and further to about 0.503 during the more recent period of floating exchange rates (1972-1992). Huang, Liu and Phaneuf (2004), suggest that this is difficult to be explained purely by aggregate supply shocks alone and they attribute this to an ever increasing use of intermediate goods in the US. We too share this view, because as we 
show the nature of aggregate shocks alone could not explain an ever increasing trend in real wage procyclicality. However, we also find that within shorter periods none of the countries we examine, including the US, exhibit an ever increasing real wage procyclicality.

In fact, the evidence provided by Basu and Taylor (1999) is still consistent within our theoretical model where switches in monetary policy preferences in combination with the nature of shocks can determine the direction and degree of real wage cyclicality. In particular, the sustained recession in the interwar period (1919-1939) combined with relatively accommodating monetary policy could largely account for the observed real wage countercyclicality during that period. Then the Bretton Woods period with relatively low supply shocks and stable prices, but less accommodating monetary policy (constrained by the fixed exchange rates), is also consistent with our claim that such a combination should result in an increased real wage cyclicality. Also, the period 1972-1992, characterized by sizeable supply shocks, strong anti inflation policy followed by further emphasis on inflation stability, also fits the story that under such conditions we should be observing a substantial increase in real wage procyclicality. More importantly, unlike Huang, Liu and Phaneuf (2004) and the earlier studies, our results are also consistent with the drop in real wage procyclicality during the relatively stable inflation periods of the post 1980s when less contractionary monetary intervention was required. Krause and Lubik (2007), who examine the relationship between detrended real wages and GDP in the US for the period 1964-2002, show that although real wages have been procyclical in the post war years the procyclicality is much higher in the 1970s than in the 1980s or later. This evidence is consistent with the empirical evidence provided in this paper, where we show that for all six OECD countries examined, real wage procyclicality rises 
and falls within the post war period with substantial drops during the more recent periods of relatively low and stable inflation. This also suggests that real wage cyclicality in the US cannot be entirely explained by the ever increasing use of intermediate goods, as suggested by Huang, Liu and Phaneuf (2004), but must be also subject to other factors that may vary in the short run, such as the nature of aggregate shocks in combination with the response of monetary policy.

\section{References}

Abraham, K.G., and J.C. Haltiwanger. "Real Wages and the Business Cycle." Journal of Economic Literature, 33, 1995, 1215-64.

Argy, V., A. Brennan, and G. Stevens. "Monetary Targeting: The International Experience." The Economic Record, March 1990, 37-62.

Artus, P., S. Avouyi-Dovi, E. Bleuze, and F. Lecointe. "Transmission of U.S. Monetary Policy to Europe and Asymmetry in the European Monetary System." European Economic Review, 35, 1991, 1369-84.

Ball, L., and N. Sheridan. "Does Inflation Targeting Matter?" in The Inflation-Targeting Debate, edited by B.S. Bernanke, and M. Woodford. Chicago: The University of Chicago Press, 2005, 249-82.

Barth, Marvin J III, and Valerie A. Ramey (2001). "The Cost Channel of Monetary Transmission." In NBER Macroeconomics Annual, eds. Ben S. Bernanke and Kenneth Rogoff, Cambridge: MIT Press, 199-240.

Basu, S. "Technology and Business Cycles: How Well Do Standard Models Explain the Facts?" Federal Reserve Bank of Boston Conference Series, 
1998.

Basu, S., and J.G. Fernald. "Returns to Scale in U.S. Production: Estimates and Implications." Journal of Political Economy, 105 (2), 1997, 249-83.

Basu, S., and A.M. Taylor. "Business Cycles in International Historical Perspective." Journal of Economics Perspectives, 13 (2), 1999, 45-68.

Bernanke, B.S., and K. Carey. "Nominal Wage Stickiness and Aggregate Supply in the Great Depression." The Quarterly Journal of Economics, 111(3), 1996, 853-83.

Bernanke, B.S., and I. Mihov. "What Does the Bundesbank Target?" European Economic Review, 41 (6), 1997, 1025-53.

Bernanke, B.S., T. Laubach, F.S. Mishkin, and A.S. Posen. Inflation Targeting: Lessons from the International Experience. Princeton: Princeton University Press, 1999.

Bernanke, B.S., and F.S. Mishkin. "Central Bank Behavior and the Strategy of Monetary Policy: observations from Six Industrialized Countries." NBER Macroeconomics Annual, edited by O.J.Blanchard, and S. Fischer. 1992, 183-228.

Bilke, L. "Break in the Mean and Persistence of Inflation: A Sectoral Analysis of French CPI." Banque de France NER-E122, 2005.

Blanchard, O.J., and J. Galí. "The Macroeconomic Effects of Oil Shocks: Why are the 2000s So Different from the 1970s." NBER Working Paper No. 13368, 2007. 
Blanchard, O.J., and D. Quah. "The Dynamic Effects of Aggregate Demand and Supply Disturbances." The American Economic Review, 794, 1989, 655-73.

Bordo, M.D., and A.J. Schwartz. "Monetary Policy Regimes and Economic Performance: The Historical Record." in Handbook of Macroeconomics, edited by J.B. Taylor, and M. Woodford. Amsterdam: Elsevier Science B.V., 1999, 149-234.

Bowen, A. "Inflation Targetry in the United Kingdom." in Targeting Inflation, edited by A.G. Haldane. Bank of England, 1995, 59-74.

Brandolini, A. "In Search of a Stylised Fact: Do Real Wages Exhibit a Consistent Pattern of Cyclical Variability?" Journal of Economic Surveys, 9 (2), 1995, 103-63.

Bratsiotis, G.J. "Monetary Policy Responses and Strategic Price Setting." Economics Letters, 95 (3), 2007, 327-33.

Brischetto, A., and G. Voss. "A Structural Vector Autoregression Model of Monetary Policy in Australia." Reserve Bank of Australia Research Discussion Paper No. 1999-11, 1999.

Castro, R., and D. Coen-Pirani. "Why Have Aggregate Skilled Hours Become so Cyclical Since the Mid-1980s?" International Economic Review, 49 (1), 2008, 135-85.

Chirinko, R.S. "The Real Wage Rate over the Business Cycle." Review of Economic Statistics, 62 (3), 1980, 459-61. 
Christiano, L.J., M. Eichenbaum, and C. Evans. "Sticky Price and Limited Participation Models: A Comparison." European Economic Review, 41 (6), 1997, 1173-200.

Clarida, R., and M. Gertler. "How the Bundesbank Conducts Monetary Policy." NBER Working Paper No. 5581, 1996.

Clarida, R., J. Galí, and M. Gertler. "Monetary Policy Rules in Practice: Some International Evidence." European Economic Review, 42, 1998, 1033-1067.

Clarida, R., J. Galí, and M. Gertler. "The Science of Monetary Policy: A New Keynesian Perspective." Journal of Economic Literature, 37, 1999, 1661-707.

Clarida, R., J. Galí, and M. Gertler. "Monetary Policy Rules and Macroeconomic Stability: Evidence and Some Theory." The Quarterly Journal of Economics, 115, 2000, 147-80.

Debelle, G. "The Ends of Three Small Inflations: Australia, New Zealand and Canada." Canadian Public Policy/Analyse de Politiques, 22 (1), 1996, 56-78.

Dixon, H. and E. Kara. "Can We Explain Inflation Persistence in a Way that Is Consistent with the Microevidence on Nominal Rigidity?". Journal of Money, Credit and Banking, 42, 1, 2010, 151-170.

Dodge, D. "Inflation targeting in Canada: Experience and Lessons." North American Journal of Economics and Finance, 13, 2002, 113-124. 
Enders, W., and S. Hurn. "Identifying Aggregate Demand and Supply Shocks in a Small Open Economy." Oxford Economic Papers, 59, 2007, $411-29$.

Farés, J., and T. Lemieux. "Downward Nominal-Wage Rigidity: A Critical Assessment and Some New Evidence for Canada." in Proceedings of the Bank of Canada Conference on Price Stability and the Long Run Target for Monetary Policy, edited by A. Crawford. Ottawa: Bank of Canada, 2001, 3-48.

Favero, C.A., and R. Rovelli. "Macroeconomic Stability and the Preferences of the Fed: A Formal Analysis, 1961-98." Journal of Money, Credit, and Banking, 35 (4), 2003, 545-56.

Fischer, S. Long-term contracts, rational expectations, and the optimal money supply rule, Journal of Political Economy 85(1), 1977, 191-205.

Francis, N., and V.A. Ramey. "Is the Technology-driven Real Business Cycle Hypothesis Dead? Shocks and Aggregate Fluctuations Revisited." Journal of Monetary Economics. 52 (8), 2002, 1379-99.

Friedman, B.M. "Monetarism: Lessons from the Post-1979 Experiment." The American Economic Review, 74 (2), 1984, 382-87.

Friedman, Milton, and Rose Friedman (1984). The Tyranny of the Status Quo. New York: Harcourt Brace Jovanich.

Galí, J. "Technology, Employment, and the Business Cycle: Do Technology Shocks Explain Aggregate Fluctuations?" The American Economic Review, 89 (1), 1999, 249-71. 
Gavosto, A., and G. Pellegrini. "Demand and Supply Shocks in Italy: An Application to Industrial Output." European Economic Review, 43 (9), 1999, 1679-703.

Gerberding, C.H., F. Seitz, and A. Worms. "How the Bundesbank Really Conducted Monetary Policy." North American Journal of Economics and Finance, 16, 2005, 277-92.

Gerlach, S., and F. Smets. "MCIs and Monetary Policy." European Economic Review, 44, 2000, 1677-1700.

González-Hermosillo, B. and T. Ito. "The Bank of Canada's Monetary Policy Framework: Have Recent Changes Enhanced Central Bank Credibility?" International Monetary Fund Working Paper WP/97/171, 1997.

Goodfriend, M. "The Monetary Policy debate Since October 1979: Lessons for Theory and Practice." Federal Reserve Bank of St. Louis Review, 87 (2, Part 2), 2005, 243-62.

Grenville, S. "The Evolution of Monetary Policy: From Money Targets to Inflation Targets." in Monetary Policy and Inflation Targets: Reserve Bank of Australia Annual Conference Volume, 1997, 125-158.

Hoehn, J.G. "Procyclical Real Wages under Nominal-Wage Contracts with Productivity Variations." Federal Reserve Bank of Cleveland Economic Review, Q4, 1988, 11-23.

Huang, K.X.D., and Z. Liu. "Staggered Price-Setting, Staggered WageSetting, and Business Cycle Persistence." Journal of Monetary Economics, 49 (2), 2002, 405-33. 
Huang, K.X.D., and Z. Liu, and L. Phaneuf. "Why Does the Cyclical Behavior of Real Wages Change Over Time?" The American Economic Review, 94 (4), 2004, 836-56.

Judd, J.P., and G.D. Rudebusch. "Taylor's Rule and the Fed: 1970-1997." Federal Reserve Bank of San Francisco Economic Review, 3, 1998, 3-16.

Judd, J.P., G.D. Rudebusch, and B. Trehan. "Has the Fed Gotten Tougher on Inflation?" Federal Reserve Bank of San Francisco Weekly Letter, 95 (13), 1995.

Kim, K., and Y.S. Kim. "How Important is the Intermediate Input Channel in Explaining Sectoral Employment Comovement over the Business Cycle?" Review of Economic Dynamics, 9(4), 2006, 659-82

King, M. "Changes in UK Monetary Policy: Rules and Discretion in Practice." Journal of Monetary Economics, 39, 1997, 81-97.

Krause, M.U., and T.A. Lubik. "The (ir)relevance of real wage rigidity in the New Keynesian model with search frictions." Journal of Monetary Economics, 54 (3), 2007, 706-27.

Laidler, D. "The Exchange Rate Regime and Canada's Monetary Order.", Bank of Canada Working Paper 99-7, 1999.

Leiderman, L. "The Response of Real Wages to Unanticipated Money Growth." Journal of Monetary Economics, 11, 1983, 73-88.

Liu, H., A Cross-Country Comparison of the Cyclicality of Real Wages, Canadian Journal of Economics, 2003 vol. 36, no. 4, 923-948. 
Macfarlane, I.J. "Australian Monetary Policy in the Last Quarter of the Twentieth Century." The Economic Record, 75 (230), 1999, 213-24.

Malley, J.R., V.A. Muscatelli, and U. Woitek. "Real business cycles, sticky wages or sticky prices? The impact of technology shocks on US manufacturing." European Economic Review, 49 (3), 2005, 745-60.

Mehra, Y.P. "A Federal Funds Rate Equation." Economic Inquiry, 35 (3), 1997, 621-30.

Mehra, Y.P. "A Forward-Looking Monetary Policy Reaction Function." Federal Reserve Bank of Richmond Economic Quarterly, 85 (2), Spring 1999, 33-54.

Messina, J., C. Strozzi, and J. Turunen. "Real wages over the business cycle: OECD evidence from the time and frequency domains." Journal of Economic Dynamics and Control, 33 (6), 2009, 1183-200.

Miles, W. "Inflation Targeting and Monetary Policy in Canada: What is the Impact on Inflation Uncertainty?" North American Journal of Economics and Finance, 19(2), 2008, 235-248.

Nelson, E. "UK Monetary Policy 1972-97: A guide using Taylor Rules." Bank of England Working Paper No. 120, 2000.

Nelson, Edward, "The Great Inflation of the Seventies: What Really Happened?" Federal Reserve Bank of St Louis Working Paper January 2004.

Nelson, E.. "Monetary Policy Neglect and the Great Inflation in Canada, Australia, and New Zealand." International Journal of Central Banking, 1 (1), 2005, 133-79. 
Nordhaus, W.D. "Who's Afraid of a Big Bad Oil Shock?" Brookings Papers on Economic Activity, (2), 2007, 219-38.

Romer, C., and D. Romer. "Does Monetary Policy Matter? A New Test in the Spirit of Friedman and Schwartz." NBER Working Paper No. 2966, 1989.

Sargent, J. "The 1975-78, Anti-Inflation Program in Retrospect." Bank of Canada Working Paper No. 43, 2005.

Senda, T. "Determining Output and Inflation Variability: Are the Phillips Curve and the Monetary Policy Reaction Function Responsible?" Economic Inquiry, 43 (2), 2005, 439-53.

Shapiro, M.D., and M.W. Watson. "Sources of Business Cycle Fluctuations." NBER Macroeconomics Annual, edited by S. Fischer. Cambridge: MIT Press, 1988, 111-48.

Sharpe, A., J. Arsenault, and P. Harrison. "Why Have Real Wages Lagged Labour Productivity Growth in Canada?" International Productivity Monitor, 17, Fall 2008, 16-27.

Smets, F. "Measuring Monetary Policy Shocks in France, Germany and Italy: The Role of the Exchange Rate." BIS Working Paper No. 42, 1997.

Spencer, D.E. "The relative stickiness of wages and prices." Economic Inquiry, 36, 1998, 120-37.

Taylor, J.B. "Introduction," in Monetary Policy Rules, edited by J.B. Taylor. Chicago: National Bureau of Economic Research, 1999, 1-14. 
Walsh, C.E. Monetary Theory and Policy. Cambridge: MIT Press, 2003.

Weber, A.A. "Germany Before and After Unification: A Structural VAR Analysis." Economic Modelling, 13 (4), 1996, 575-601. 


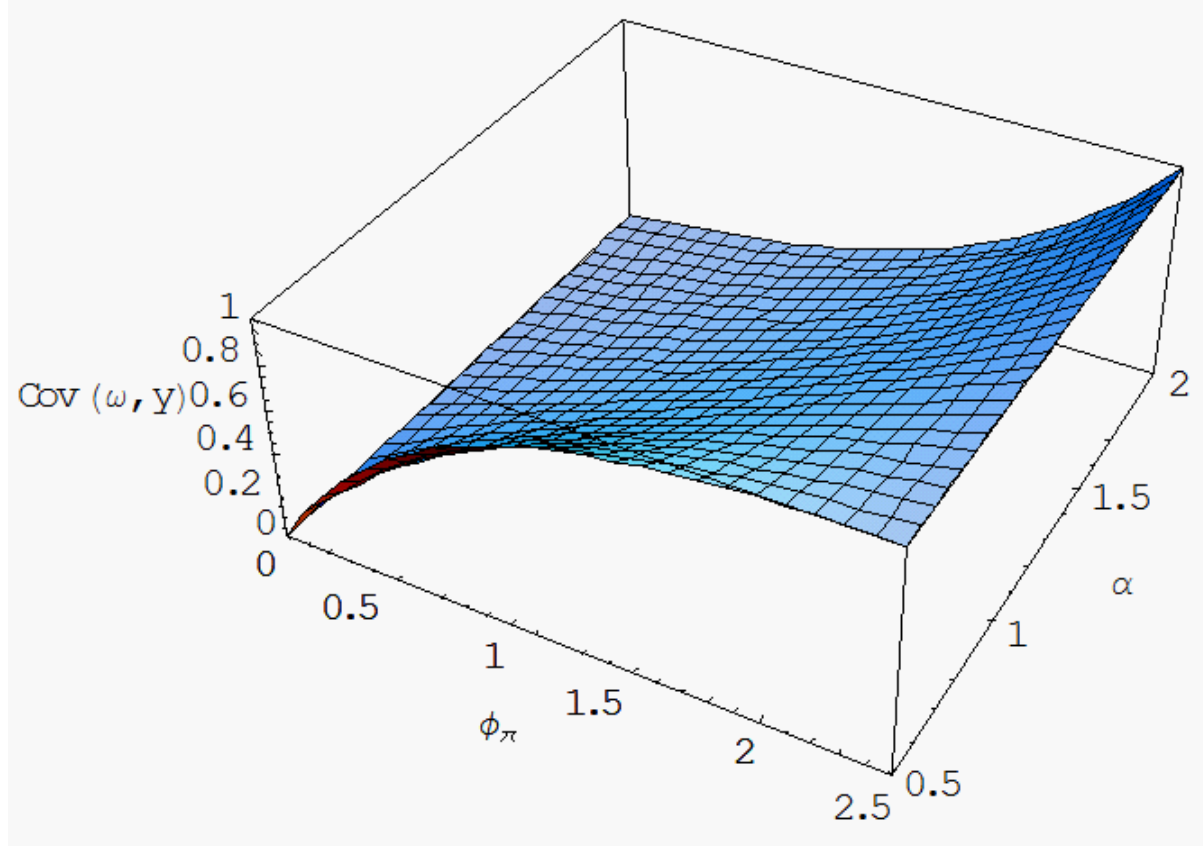

Fig. 1. Real Wage Cyclicality with varying $\phi_{\pi}$ and $\alpha$ 


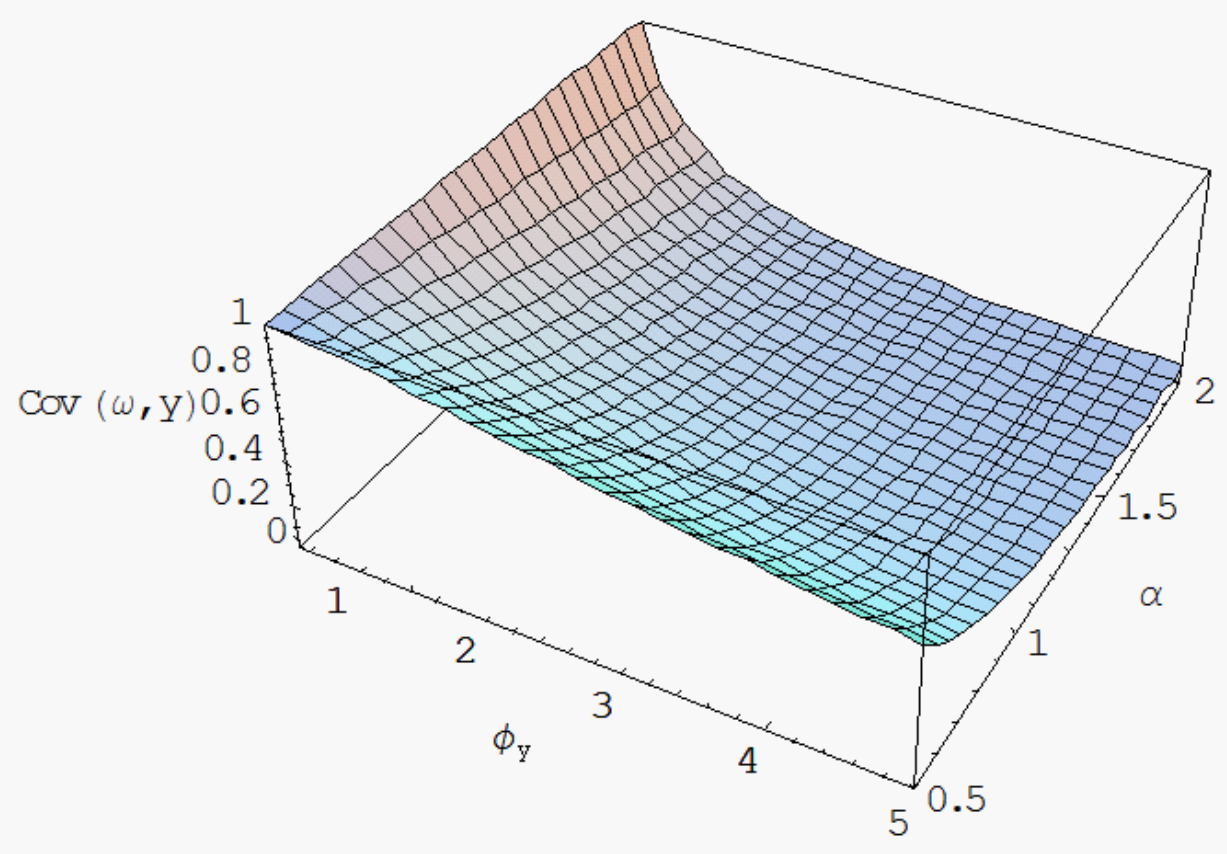

Fig. 2. Real Wage Cyalicality with varying $\phi_{Y}$ and $\alpha$ 
Table 1: GMM Estimates of the Cyclicality of Real Wages - Australia

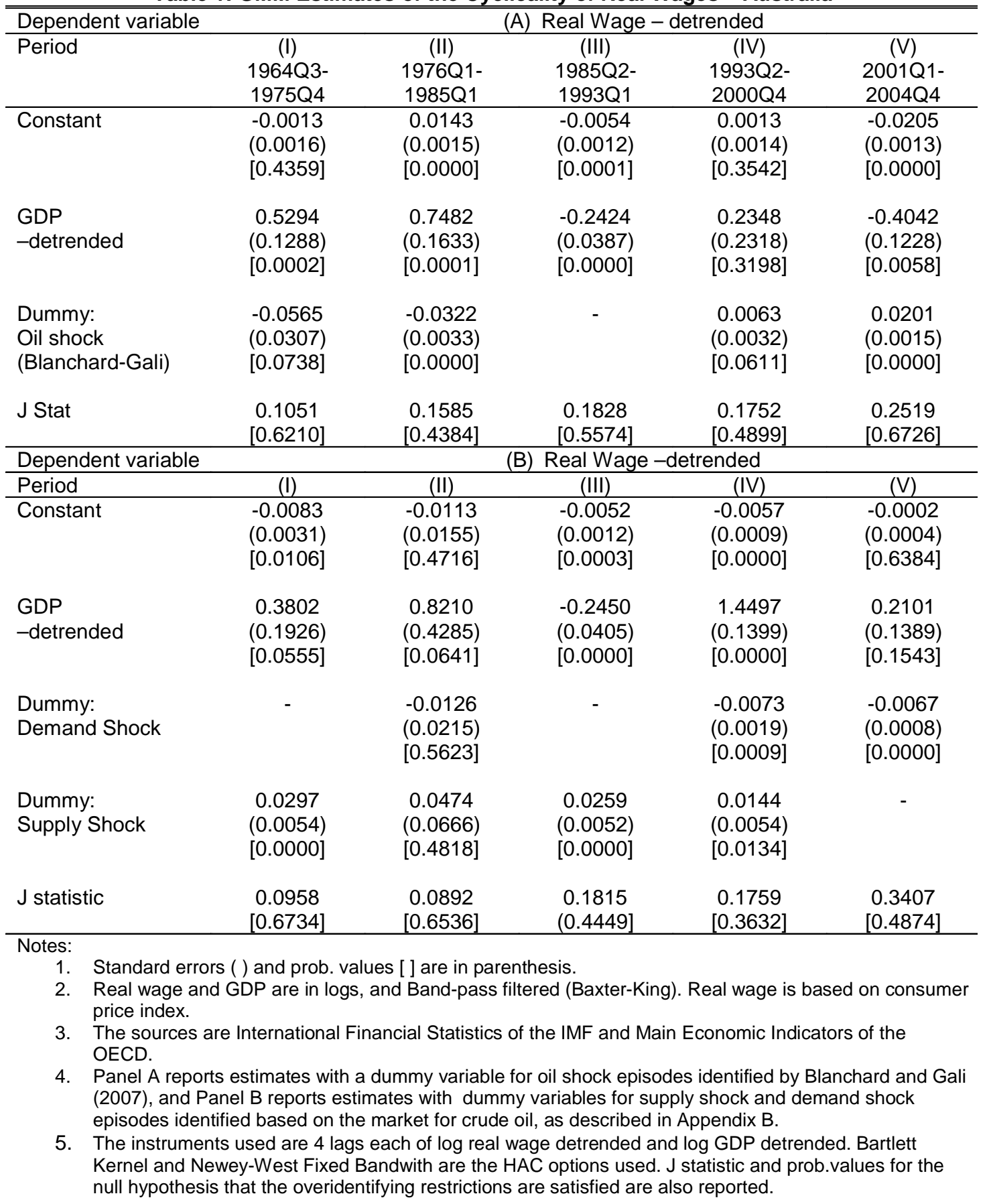


Table 2: GMM Estimates of the Cyclicality of Real Wages - Canada

\begin{tabular}{|c|c|c|c|c|c|}
\hline \multirow{2}{*}{$\begin{array}{l}\text { Dependent variable } \\
\text { Period }\end{array}$} & \multicolumn{5}{|c|}{ (A) Real Wage - detrended } \\
\hline & $\begin{array}{c}(I) \\
\text { 1963Q1- } \\
\text { 1975Q2 }\end{array}$ & $\begin{array}{c}\text { (II) } \\
\text { 1975Q3- } \\
\text { 1978Q2 }\end{array}$ & $\begin{array}{c}\text { (III) } \\
\text { 1978Q3- } \\
\text { 1987Q4 }\end{array}$ & $\begin{array}{c}(I V) \\
\text { 1988Q1- } \\
\text { 1991Q1 }\end{array}$ & $\begin{array}{c}(V) \\
\text { 1991Q2- } \\
\text { 2004Q4 }\end{array}$ \\
\hline Constant & $\begin{array}{l}-0.0037 \\
(0.0012) \\
{[0.0038]}\end{array}$ & $\begin{array}{c}0.0222 \\
(0.0009) \\
{[0.0000]}\end{array}$ & $\begin{array}{l}-0.0049 \\
(0.0006) \\
{[0.0000]}\end{array}$ & $\begin{array}{l}-0.0060 \\
(0.0000) \\
{[0.0000]}\end{array}$ & $\begin{array}{l}-0.0073 \\
(0.0044) \\
{[0.1005]}\end{array}$ \\
\hline $\begin{array}{l}\text { GDP } \\
\text {-detrended }\end{array}$ & $\begin{array}{l}-0.1630 \\
(0.0941) \\
{[0.0906]}\end{array}$ & $\begin{array}{l}2.2151 \\
(0.0909) \\
{[0.0000]}\end{array}$ & $\begin{array}{l}-0.1165 \\
(0.0178) \\
{[0.0000]}\end{array}$ & $\begin{array}{l}-0.0259 \\
(0.0032) \\
{[0.0000]}\end{array}$ & $\begin{array}{l}-0.3887 \\
(0.1562) \\
{[0.0160]}\end{array}$ \\
\hline $\begin{array}{l}\text { Dummy: } \\
\text { Oil shock } \\
\text { (Blanchard-Gali) }\end{array}$ & $\begin{array}{l}-0.0539 \\
(0.0285) \\
{[0.0651]}\end{array}$ & - & $\begin{array}{c}0.0046 \\
(0.0017) \\
{[0.0115]}\end{array}$ & - & $\begin{array}{c}0.0246 \\
(0.0111) \\
{[0.0307]}\end{array}$ \\
\hline J Stat & $\begin{array}{c}0.1067 \\
{[0.5556]}\end{array}$ & $\begin{array}{c}0.3265 \\
{[0.7892]}\end{array}$ & $\begin{array}{c}0.1386 \\
{[0.5098]}\end{array}$ & $\begin{array}{c}0.3352 \\
{[0.7377]}\end{array}$ & $\begin{array}{c}0.0707 \\
{[0.6920]}\end{array}$ \\
\hline Dependent variable & & & eal Wage - & ded & \\
\hline Period & (I) & (II) & (III) & (IV) & $(\mathrm{V})$ \\
\hline Constant & $\begin{array}{l}-0.0034 \\
(0.0014) \\
{[0.0167]}\end{array}$ & $\begin{array}{c}0.0363 \\
(0.0003) \\
{[0.0000]}\end{array}$ & $\begin{array}{l}-0.0047 \\
(0.0006) \\
{[0.0000]}\end{array}$ & $\begin{array}{l}-0.0060 \\
(0.0000) \\
{[0.0000]}\end{array}$ & $\begin{array}{c}0.0000 \\
(0.0022) \\
{[0.9945]}\end{array}$ \\
\hline $\begin{array}{l}\text { GDP } \\
\text {-detrended }\end{array}$ & $\begin{array}{l}-0.1628 \\
(0.1208) \\
{[0.1849]}\end{array}$ & $\begin{array}{c}0.6940 \\
(0.0132) \\
{[0.0000]}\end{array}$ & $\begin{array}{l}-0.1101 \\
(0.0147) \\
{[0.0000]}\end{array}$ & $\begin{array}{l}-0.0259 \\
(0.0032) \\
{[0.0000]}\end{array}$ & $\begin{array}{c}0.2136 \\
(0.2331) \\
{[0.3640]}\end{array}$ \\
\hline $\begin{array}{l}\text { Dummy: } \\
\text { Demand Shock }\end{array}$ & - & - & $\begin{array}{c}0.0039 \\
(0.0016) \\
{[0.0224]}\end{array}$ & - & $\begin{array}{l}-0.0308 \\
(0.0154) \\
{[0.0508]}\end{array}$ \\
\hline $\begin{array}{l}\text { Dummy: } \\
\text { Supply Shock }\end{array}$ & $\begin{array}{l}0.0245 \\
(0.0081) \\
{[0.0043]}\end{array}$ & $\begin{array}{l}-0.0327 \\
(0.0003) \\
{[0.0000]}\end{array}$ & $\begin{array}{l}0.0032 \\
(0.0009) \\
{[0.0009]}\end{array}$ & - & $\begin{array}{c}0.0781 \\
(0.0759) \\
{[0.3083]}\end{array}$ \\
\hline J statistic & $\begin{array}{c}0.1198 \\
{[0.4799]}\end{array}$ & $\begin{array}{c}0.2504 \\
{[0.8082]}\end{array}$ & $\begin{array}{c}0.1441 \\
{[0.3606]}\end{array}$ & $\begin{array}{c}0.3352 \\
{[0.7377]}\end{array}$ & $\begin{array}{c}0.0780 \\
{[0.5082]}\end{array}$ \\
\hline
\end{tabular}

1. Standard errors ( ) and prob. values [ ] are in parenthesis.

2. Real wage and GDP are in logs, and Band-pass filtered (Baxter-King). Real wage is based on consumer price index.

3. The sources are International Financial Statistics of the IMF and Main Economic Indicators of the OECD.

4. Panel A reports estimates with a dummy variable for oil shock episodes identified by Blanchard and Gali (2007), and Panel B reports estimates with dummy variables for supply shock and demand shock episodes identified based on the market for crude oil, as described in Appendix B.

5. The instruments used are 4 lags each of log real wage detrended and log GDP detrended. Bartlett Kernel and Newey-West Fixed Bandwith are the HAC options used. J statistic and prob.values for the null hypothesis that the overidentifying restrictions are satisfied are also reported. 
Table 3: GMM Estimates of the Cyclicality of Real Wages - France

\begin{tabular}{|c|c|c|c|c|c|}
\hline \multirow{2}{*}{$\begin{array}{l}\text { Dependent variable } \\
\text { Period }\end{array}$} & \multicolumn{5}{|c|}{ (A) Real Wage - detrended } \\
\hline & $\begin{array}{c}(\mathrm{I}) \\
\text { 1963Q1- } \\
\text { 1979Q1 }\end{array}$ & $\begin{array}{c}(\mathrm{II}) \\
\text { 1979Q2-1983q1 }\end{array}$ & $\begin{array}{c}(I I I) \\
\text { 1983Q2- } \\
\text { 1985Q4 }\end{array}$ & $\begin{array}{c}\text { (III) } \\
\text { 1986Q1- } \\
\text { 1998Q4 }\end{array}$ & $\begin{array}{c}(I V) \\
\text { 1999Q1- } \\
\text { 2004Q4 }\end{array}$ \\
\hline Constant & $\begin{array}{l}-0.0023 \\
(0.0018) \\
{[0.2076]}\end{array}$ & $\begin{array}{c}0.0089 \\
(0.0021) \\
{[0.0010]}\end{array}$ & $\begin{array}{c}0.0111 \\
(0.0002) \\
{[0.0000]}\end{array}$ & $\begin{array}{c}0.0003 \\
(0.0010) \\
{[0.7907]}\end{array}$ & $\begin{array}{c}0.0067 \\
(0.0017) \\
{[0.0007]}\end{array}$ \\
\hline $\begin{array}{l}\text { GDP } \\
\text {-detrended }\end{array}$ & $\begin{array}{l}-1.2506 \\
(0.2300) \\
{[0.0000]}\end{array}$ & $\begin{array}{c}3.3849 \\
(0.4642) \\
{[0.0000]}\end{array}$ & $\begin{array}{l}2.2872 \\
(0.0490) \\
{[0.0000]}\end{array}$ & $\begin{array}{l}-0.4707 \\
(0.1033) \\
{[0.0000]}\end{array}$ & $\begin{array}{l}-0.2673 \\
(0.0431) \\
{[0.0000]}\end{array}$ \\
\hline $\begin{array}{l}\text { Dummy: } \\
\text { Oil shock } \\
\text { (Blanchard-Gali) }\end{array}$ & $\begin{array}{c}0.0762 \\
(0.0338) \\
{[0.0277]}\end{array}$ & $\begin{array}{l}-0.0410 \\
(0.0076) \\
{[0.0001]}\end{array}$ & - & - & $\begin{array}{l}-0.0015 \\
(0.0019) \\
{[0.4472]}\end{array}$ \\
\hline J Stat & $\begin{array}{c}0.1179 \\
{[0.3035]}\end{array}$ & $\begin{array}{c}0.2528 \\
{[0.6705]}\end{array}$ & $\begin{array}{c}0.3426 \\
{[0.8060]}\end{array}$ & $\begin{array}{c}0.1669 \\
{[0.2763]}\end{array}$ & $\begin{array}{c}0.2447 \\
{[0.4375]}\end{array}$ \\
\hline Dependent variable & & (B) & eal Wage - & ded & \\
\hline Period & (I) & (II) & (III) & (IV) & $(\mathrm{V})$ \\
\hline Constant & $\begin{array}{l}-0.0080 \\
(0.0018) \\
{[0.0000]}\end{array}$ & $\begin{array}{c}0.0089 \\
(0.0021) \\
{[0.0010]}\end{array}$ & $\begin{array}{c}0.0112 \\
(0.0002) \\
{[0.0000]}\end{array}$ & $\begin{array}{c}0.0000 \\
(0.0010) \\
{[0.9508]}\end{array}$ & $\begin{array}{l}-0.0011 \\
(0.0009) \\
{[0.2144]}\end{array}$ \\
\hline $\begin{array}{l}\text { GDP } \\
\text {-detrended }\end{array}$ & $\begin{array}{l}-0.1861 \\
(0.1664) \\
{[0.2680]}\end{array}$ & $\begin{array}{c}3.3849 \\
(0.4642) \\
{[0.0000]}\end{array}$ & $\begin{array}{l}2.2601 \\
(0.0561) \\
{[0.0000]}\end{array}$ & $\begin{array}{l}-0.4306 \\
(0.1071) \\
{[0.0002]}\end{array}$ & $\begin{array}{l}-0.3149 \\
(0.0640) \\
{[0.0001]}\end{array}$ \\
\hline $\begin{array}{l}\text { Dummy: } \\
\text { Demand Shock }\end{array}$ & - & $\begin{array}{l}-0.0410 \\
(0.0076) \\
{[0.0001]}\end{array}$ & - & - & $\begin{array}{c}0.0069 \\
(0.0016) \\
{[0.0003]}\end{array}$ \\
\hline $\begin{array}{l}\text { Dummy: } \\
\text { Supply Shock }\end{array}$ & $\begin{array}{c}0.0203 \\
(0.0038) \\
{[0.0000]}\end{array}$ & - & $\begin{array}{l}-0.0079 \\
(0.0005) \\
{[0.0000]}\end{array}$ & $\begin{array}{l}-0.0042 \\
(0.0041) \\
{[0.3100]}\end{array}$ & - \\
\hline J statistic & $\begin{array}{c}0.1239 \\
{[0.2721]}\end{array}$ & $\begin{array}{c}0.2528 \\
{[0.6705]}\end{array}$ & $\begin{array}{c}0.3245 \\
{[0.7347]}\end{array}$ & $\begin{array}{c}0.1695 \\
{[0.1844]}\end{array}$ & $\begin{array}{c}0.2455 \\
{[0.4355]}\end{array}$ \\
\hline
\end{tabular}

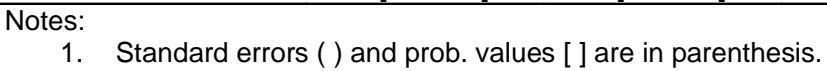

2. Real wage and GDP are in logs, and Band-pass filtered (Baxter-King). Real wage is based on consumer price index.

3. The sources are International Financial Statistics of the IMF and Main Economic Indicators of the OECD.

4. Panel A reports estimates with a dummy variable for oil shock episodes identified by Blanchard and Gali (2007), and Panel B reports estimates with dummy variables for supply shock and demand shock episodes identified based on the market for crude oil, as described in Appendix B.

5. The instruments used are 4 lags each of log real wage detrended and log GDP detrended. Bartlett Kernel and Newey-West Fixed Bandwith are the HAC options used. J statistic and prob.values for the null hypothesis that the overidentifying restrictions are satisfied are also reported. 
Table 4: GMM Estimates of the Cyclicality of Real Wages - Germany

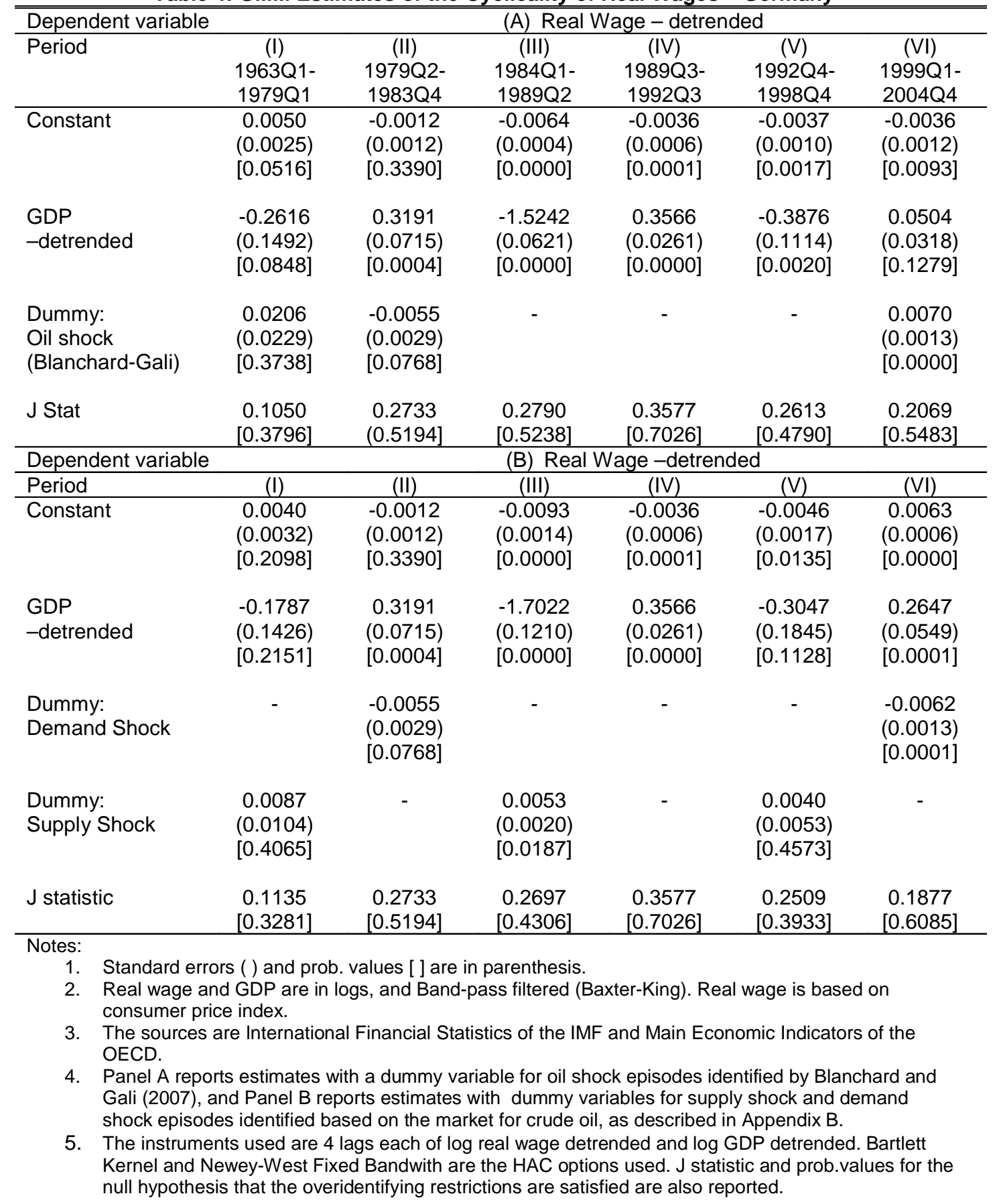


Table 5: GMM Estimates of the Cyclicality of Real Wages - United Kingdom

\begin{tabular}{|c|c|c|c|c|}
\hline Dependent variable & & (A) $\mathrm{R}$ & ge-detre & \\
\hline Period & $\begin{array}{c}(\mathrm{I}) \\
\text { 1966Q1- } \\
\text { 1979Q2 }\end{array}$ & $\begin{array}{c}\text { (II) } \\
\text { 1979Q3- } \\
\text { 1987Q1 }\end{array}$ & $\begin{array}{c}\text { (III) } \\
\text { 1987Q2- } \\
\text { 1992Q3 }\end{array}$ & $\begin{array}{c}\text { IV }) \\
\text { 1992Q4- } \\
\text { 2004Q4 }\end{array}$ \\
\hline Constant & $\begin{array}{c}0.0100 \\
(0.0026) \\
{[0.0003]}\end{array}$ & $\begin{array}{c}0.0010 \\
(0.0004) \\
{[0.0223]}\end{array}$ & $\begin{array}{l}-0.0021 \\
(0.0002) \\
{[0.0000]}\end{array}$ & $\begin{array}{l}-0.0053 \\
(0.0022) \\
{[0.0239]}\end{array}$ \\
\hline $\begin{array}{l}\text { GDP } \\
\text {-detrended }\end{array}$ & $\begin{array}{c}0.4809 \\
(0.1628) \\
{[0.0049]}\end{array}$ & $\begin{array}{c}0.6491 \\
(0.0686) \\
{[0.0000]}\end{array}$ & $\begin{array}{c}0.5468 \\
(0.0120) \\
{[0.0000]}\end{array}$ & $\begin{array}{l}-0.1132 \\
(0.1338) \\
{[0.4017]}\end{array}$ \\
\hline $\begin{array}{l}\text { Dummy: } \\
\text { Oil shock } \\
\text { (Blanchard-Gali) }\end{array}$ & $\begin{array}{l}-0.0271 \\
(0.0079) \\
{[0.0013]}\end{array}$ & $\begin{array}{l}-0.0175 \\
(0.0021) \\
{[0.0000]}\end{array}$ & - & $\begin{array}{c}0.0096 \\
(0.0035) \\
{[0.0077]}\end{array}$ \\
\hline J Stat & $\begin{array}{c}0.1215 \\
{[0.4150]}\end{array}$ & $\begin{array}{c}0.1723 \\
{[0.5008]}\end{array}$ & $\begin{array}{c}0.2583 \\
{[0.5771]}\end{array}$ & $\begin{array}{c}0.1033 \\
{[0.5358]}\end{array}$ \\
\hline Dependent variable & & (B) $\mathrm{F}$ & ge -detre & \\
\hline Period & (I) & (II) & (III) & (IV) \\
\hline Constant & $\begin{array}{l}-0.0217 \\
(0.0096) \\
{[0.0293]}\end{array}$ & $\begin{array}{l}-0.0002 \\
(0.0015) \\
{[0.8871]}\end{array}$ & $\begin{array}{l}-0.0021 \\
(0.0002) \\
{[0.0000]}\end{array}$ & $\begin{array}{l}-0.0024 \\
(0.0009) \\
{[0.0102]}\end{array}$ \\
\hline $\begin{array}{l}\text { GDP } \\
\text {-detrended }\end{array}$ & $\begin{array}{l}-1.1254 \\
(0.5998) \\
{[0.0670]}\end{array}$ & $\begin{array}{c}0.8466 \\
(0.0948) \\
{[0.0000]}\end{array}$ & $\begin{array}{c}0.5468 \\
(0.0120) \\
{[0.0000]}\end{array}$ & $\begin{array}{c}0.0538 \\
(0.0581) \\
{[0.3595]}\end{array}$ \\
\hline $\begin{array}{l}\text { Dummy: } \\
\text { Demand Shock }\end{array}$ & $\begin{array}{c}0.1000 \\
(0.0927) \\
{[0.2863]}\end{array}$ & $\begin{array}{l}-0.0217 \\
(0.0041) \\
{[0.0000]}\end{array}$ & - & $\begin{array}{c}0.0063 \\
(0.0016) \\
{[0.0003]}\end{array}$ \\
\hline $\begin{array}{l}\text { Dummy: } \\
\text { Supply Shock }\end{array}$ & $\begin{array}{c}0.0791 \\
(0.0269) \\
{[0.0051]}\end{array}$ & $\begin{array}{c}0.0060 \\
(0.0066) \\
{[0.3761]}\end{array}$ & - & $\begin{array}{l}-0.0108 \\
(0.0090) \\
{[0.2370]}\end{array}$ \\
\hline J statistic & $\begin{array}{c}0.0567 \\
{[0.7251]}\end{array}$ & $\begin{array}{c}0.1097 \\
{[0.6384]}\end{array}$ & $\begin{array}{c}0.2583 \\
{[0.5771]}\end{array}$ & $\begin{array}{c}0.1502 \\
{[0.1951]}\end{array}$ \\
\hline
\end{tabular}

Notes:

1. Standard errors ( ) and prob. values [ ] are in parenthesis.

2. Real wage and GDP are in logs, and Band-pass filtered (Baxter-King). Real wage is based on consumer price index.

3. The sources are International Financial Statistics of the IMF and Main Economic Indicators of the OECD.

4. Panel A reports estimates with a dummy variable for oil shock episodes identified by Blanchard and Gali (2007), and Panel B reports estimates with dummy variables for supply shock and demand shock episodes identified based on the market for crude oil, as described in Appendix B.

5. The instruments used are 4 lags each of log real wage detrended and log GDP detrended. Bartlett Kernel and Newey-West Fixed Bandwith are the HAC options used. J statistic and prob.values for the null hypothesis that the overidentifying restrictions are satisfied are also reported. 
Table 6: GMM Estimates of the Cyclicality of Real Wages - United States

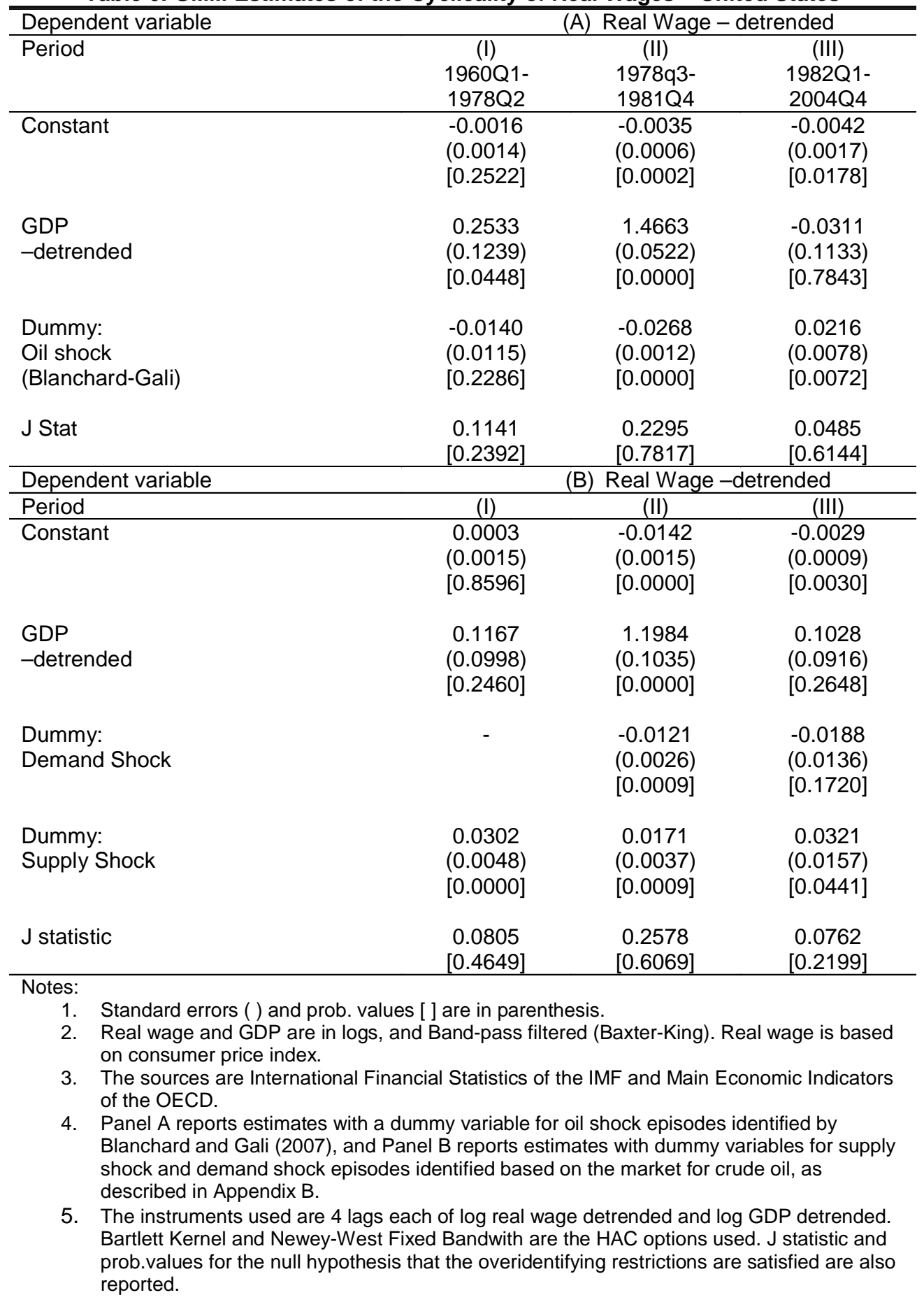




\section{$7 \quad$ Appendix (Not for publishing)}

\section{Appendix A: Derivation of Equations (17) and (18)}

Take expectations in nominal wage equation (12):

$$
w_{t}=E_{t-1} p_{t}+\frac{\alpha+\gamma \sigma}{\alpha \sigma} E_{t-1} y_{t}
$$

Substitute (A1) and the aggregate demand equation (16) into the price equation (11), subtract $p_{t-1}$ from both sides, and solve for $\pi_{t} \equiv p_{t}-p_{t-1}$ :

$$
\begin{aligned}
\pi_{t}= & \frac{\sigma(1-\alpha) \phi_{\pi} \pi^{*}}{\sigma(1-\alpha) \phi_{\pi}+\alpha\left(1+\sigma \phi_{y}\right)}+\frac{\alpha\left(1+\sigma \phi_{y}\right)}{\sigma(1-\alpha) \phi_{\pi}+\alpha\left(1+\sigma \phi_{y}\right)} E_{t-1} \pi_{t} \\
& +\frac{\sigma(1-\alpha)}{\sigma(1-\alpha) \phi_{\pi}+\alpha\left(1+\sigma \phi_{y}\right)} E_{t} \pi_{t+1}+\frac{(\alpha+\gamma \sigma)\left(1+\sigma \phi_{y}\right)}{\sigma\left(\sigma(1-\alpha) \phi_{\pi}+\alpha\left(1+\sigma \phi_{y}\right)\right)} E_{t-1} y_{t} \\
& +\frac{(1-\alpha)}{\sigma(1-\alpha) \phi_{\pi}+\alpha\left(1+\sigma \phi_{y}\right)} E_{t} y_{t+1}-\frac{\sigma(1-\alpha)}{\sigma(1-\alpha) \phi_{\pi}+\alpha\left(1+\sigma \phi_{y}\right)} d_{t} \\
& -\frac{\left(1+\sigma \phi_{y}\right)}{\sigma(1-\alpha) \phi_{\pi}+\alpha\left(1+\sigma \phi_{y}\right)} z_{t} .
\end{aligned}
$$

Following Blanchard and Galí (2007), propose a guessed solution for the inflation process of the form:

$$
\pi_{t}=A_{1}+A_{2} d_{t}+A_{3} z_{t} .
$$

so $\pi_{t+1}$ can be written as:

$$
\pi_{t+1}=A_{1}+A_{2} d_{t+1}+A_{3} z_{t+1}
$$

Forming expectations at time $t-1$ of (A3) and (A4) we obtain:

$$
E_{t-1} \pi_{t}=E_{t-1} \pi_{t+1}=E_{t} \pi_{t+1}=A_{1}
$$

Similarly for the output process given by equation (17), the guess solutions for $y_{t}$ and $y_{t+1}$ are:

$$
y_{t}=B_{1}+B_{2} d_{t}+B_{3} z_{t}
$$




$$
y_{t+1}=B_{1}+B_{2} d_{t+1}+B_{3} z_{t+1}
$$

From (A6) and (A7) we form the following expectations,

$$
E_{t-1} y_{t}=E_{t-1} y_{t+1}=E_{t} y_{t+1}=B_{1}
$$

Substitute (A8) into (A2) and (16), and solve simultaneously to determine the coefficients:

$$
\begin{aligned}
& A_{1}=\frac{\phi_{\pi} \pi^{*}}{\phi_{\pi}-1}, \\
& A_{2}=-\frac{(1-\alpha) \sigma}{\sigma(1-\alpha) \phi_{\pi}+\alpha\left(1+\sigma \phi_{y}\right)} \\
& A_{3}=-\frac{1+\sigma \phi_{y}}{\sigma(1-\alpha) \phi_{\pi}+\alpha\left(1+\sigma \phi_{y}\right)} . \\
& B_{1}=0, \\
& B_{2}=-\frac{\alpha \sigma}{\sigma(1-\alpha) \phi_{\pi}+\alpha\left(1+\sigma \phi_{y}\right)}, \\
& B_{3}=\frac{\sigma \phi_{\pi}}{\sigma(1-\alpha) \phi_{\pi}+\alpha\left(1+\sigma \phi_{y}\right)} .
\end{aligned}
$$

Substituting (A9) into (A3) we obtain the reduced-form inflation equation and by substituting (A10) into the guess solution for output (A6), we obtain the reduced-form output equation as shown in (17) in the text:

$$
y_{t}=-\frac{\alpha \sigma}{\alpha\left(1+\sigma \phi_{y}\right)+\sigma(1-\alpha) \phi_{\pi}} d_{t}+\frac{\sigma \phi_{\pi}}{\alpha\left(1+\sigma \phi_{y}\right)+\sigma(1-\alpha) \phi_{\pi}} z_{t},
$$

To solve for the reduced-form real wage equation, we rewrite equation (11) as:

$$
\omega_{t} \equiv w_{t}-p_{t}=-\frac{(1-\alpha)}{\alpha} y_{t}+\frac{1}{\alpha} z_{t}
$$

where $\omega_{t}$ denotes the real wage. Substituting (17) into (A11) we obtain equation (18) in the text:

$$
\omega_{t}=\frac{(1-\alpha)}{\alpha\left(1+\sigma \phi_{y}\right)+\sigma(1-\alpha) \phi_{\pi}} d_{t}+\frac{1+\sigma \phi_{y}}{\alpha\left(1+\sigma \phi_{y}\right)+\sigma(1-\alpha) \phi_{\pi}} z_{t}
$$




\section{Appendix B: Identifying Aggregate Demand and Aggregate Sup- ply shocks}

Most of the empirical studies that deal with aggregate demand and supply shocks in business cycle analysis use structural VAR specifications following Blanchard and Quah (1989) and Shapiro and Watson (1988) or variants of these two studies (Chirinko 1980, Leiderman 1983, Gavosto and Pellegrini 1999, and Nordhaus 2007). However, these models attempt to assess the effects of demand and supply shocks on cyclical variables through identifying restrictions and do not yield separate series for demand and supply shocks. Moreover, oil prices can be driven by either demand- or supply-side factors, and observing the behaviour of both prices and quantity simultaneously allows whether a particular oil shock episode is demand- or supply-driven. (See also Walsh, 2003, and Enders and Hurn, 2007). Given this we attempt to identify demand and supply shocks based on the market for crude oil as follows: Log crude oil production and log crude oil prices are detrended using the HP filter. The two detrended series are then compared to one standard deviation bands around the respective means. Any movement of the two detrended series beyond the bands are identified as quantity shocks and

price shocks respectively. Where the quantity shocks and price shocks do not overlap, the direction of the movement of the other series is recorded. Comparing the direction of quantity shocks and price shocks, the dominant shock in a given quarter can be identified. If both series move in the same direction, the dominant shock is identified as a "demand shock" and if the two series move in the opposite directions, the dominant shock will be a "supply shock". Periods where there is no significant shift in either quantity or price are identified as periods without shocks. Whether one uses nominal crude oil prices or crude oil prices in real terms (using world consumer 
price index), the identification of periods as demand shock- or supply shockdominant are almost identical (results differ only in 4 quarters out of 192 quarters). For the final analysis, demand and supply shocks which have a duration of less than one year are dropped. Accordingly, the identified supply shock periods are 1972Q3-1973Q4, 1974Q4-1976Q1, 1977Q4-1979Q1, 1985Q4-1986Q4, 1998Q1-1998Q4, while the identified demand shock periods are 1979Q2-1980Q2, 2000Q1-2000Q4, 2001Q4-2002Q4. Supply shocks and demand shocks identified as above are used as dummy variables in the analysis .

\section{Appendix C: Data and Sources}

All series are Quarterly Index Numbers $(2000 \mathrm{Y}=100)$. Where the original series are not seasonally adjusted at source; they have been adjusted using Census X12- ARIMA.

Australia

Prices: CPI; International Financial Statistics- IMF (19364ZF).

Wages: Weekly Earnings; International Financial Statistics- IMF (19365ZF).

Output: GDP Volume; International Financial Statistics- IMF (19399BVRZF).

Canada

Prices: CPI; International Financial Statistics- IMF (15664ZF).

Wages: Manufacturing Hourly Earnings; International Financial Statistics-IMF (15665EY.ZF).

Output: GDP Volume; International Financial Statistics- IMF (15699BVRZF).

France

Prices: CPI; International Financial Statistics- IMF (13264ZF).

Wages: Labor Costs; International Financial Statistics- IMF (13265ZF).

Output: GDP Volume; International Financial Statistics- IMF (13299BVRZF). 


\section{Germany}

Prices: CPI; Main Economic Indicators- OECD (DEU.CPALTT01.IXOB).

Wages: Manufacturing Hourly Wage Rate; Main Economic Indicators-OECD (DEU.LCWRMN01.IXOB).

Output: GDP Volume; International Financial Statistics-IMF (13499BVRZF).

\section{United Kingdom}

Prices: CPI; Main Economic Indicators- OECD (GBR.CPALTT01.IXOB).

Wages: Manufacturing Weekly Earnings; Main Economic Indicators-OECD (GBR.LCEAMN02.IXOB).

Output: GDP Volume; International Financial Statistics-IMF (11299BVRZF).

United States

Prices: CPI; International Financial Statistics-IMF (11164ZF).

Wages: Manufacturing Hourly Earnings; International Financial Statistics-IMF (11165EY.ZF).

Output: GDP Volume; International Financial Statistics-IMF (11199BVRZF).

\section{Oil Prices and Production}

Production: World Crude Oil Production (Million Barrels per Day);

Energy Information Administration (AIE), Annual Energy Review 2006.

Price: Petroleum Average Crude Price (US Dollars per Barrel): IFS -IMF (00176AAZZF). 


\section{Appendix D: Testing Real Wage Cyclicality using OLS}

Table 1a: OLS Estimates of the Cyclicality of Real Wages - Australia

\begin{tabular}{|c|c|c|c|c|c|}
\hline \multirow{2}{*}{$\begin{array}{l}\text { Dependent variable } \\
\text { Period }\end{array}$} & \multicolumn{5}{|c|}{ (A) Real Wage - detrended } \\
\hline & $\begin{array}{c}(\mathrm{I}) \\
\text { 1964Q3- } \\
\text { 1975Q4 }\end{array}$ & $\begin{array}{c}\text { (II) } \\
\text { 1976Q1- } \\
\text { 1985Q1 }\end{array}$ & $\begin{array}{c}(I I I) \\
\text { 1985Q2- } \\
\text { 1993Q1 }\end{array}$ & $\begin{array}{c}(I V) \\
\text { 1993Q2- } \\
2000 Q 4\end{array}$ & $\begin{array}{c}(\mathrm{V}) \\
2001 \mathrm{Q} 1- \\
2004 Q 4\end{array}$ \\
\hline Constant & $\begin{array}{c}0.0030 \\
(0.0045) \\
{[0.5118]}\end{array}$ & $\begin{array}{c}0.0063 \\
(0.0041) \\
{[0.1291]}\end{array}$ & $\begin{array}{l}-0.0024 \\
(0.0031) \\
{[0.4480]}\end{array}$ & $\begin{array}{l}-0.0002 \\
(0.0042) \\
{[0.9648]}\end{array}$ & $\begin{array}{l}-0.0096 \\
(0.0027) \\
{[0.0004]}\end{array}$ \\
\hline $\begin{array}{l}\text { GDP } \\
\text {-detrended }\end{array}$ & $\begin{array}{c}0.2420 \\
(0.2979) \\
{[0.4179]}\end{array}$ & $\begin{array}{c}0.4292 \\
(0.2571) \\
{[0.0971]}\end{array}$ & $\begin{array}{l}-0.2456 \\
(0.1341) \\
{[0.0691]}\end{array}$ & $\begin{array}{c}0.9814 \\
0.4256) \\
{[0.0225]}\end{array}$ & $\begin{array}{c}0.1780 \\
(0.2095) \\
{[0.3970]}\end{array}$ \\
\hline $\begin{array}{l}\text { Dummy: } \\
\text { Oil shock } \\
\text { (Blanchard-Gali) }\end{array}$ & $\begin{array}{l}-0.0225 \\
(0.0031) \\
{[0.0000]}\end{array}$ & $\begin{array}{l}-0.0183 \\
(0.0047) \\
{[0.0001]}\end{array}$ & - & $\begin{array}{l}-0.0042 \\
(0.0066) \\
{[0.5286]}\end{array}$ & $\begin{array}{c}0.0085 \\
(0.0044) \\
{[0.0532]}\end{array}$ \\
\hline Dependent variable & & & eal Wage - & hded & \\
\hline Period & (I) & (II) & (III) & $(\mathrm{IV})$ & $(\mathrm{V})$ \\
\hline Constant & $\begin{array}{l}-0.0003 \\
(0.0034) \\
{[0.9232]}\end{array}$ & $\begin{array}{c}0.0061 \\
(0.0048) \\
{[0.2080]}\end{array}$ & $\begin{array}{l}-0.0043 \\
(0.0029) \\
{[0.1481]}\end{array}$ & $\begin{array}{l}-0.0020 \\
(0.0031) \\
{[0.5221]}\end{array}$ & $\begin{array}{l}-0.0014 \\
(0.0024) \\
{[0.5579]}\end{array}$ \\
\hline $\begin{array}{l}\text { GDP } \\
\text {-detrended }\end{array}$ & $\begin{array}{c}0.1291 \\
(0.3392) \\
{[0.7039]}\end{array}$ & $\begin{array}{c}0.4208 \\
(0.2598) \\
{[0.1074]}\end{array}$ & $\begin{array}{l}-0.2334 \\
(0.1510) \\
{[0.1242]}\end{array}$ & $\begin{array}{c}0.7378 \\
(0.3115) \\
{[0.0192]}\end{array}$ & $\begin{array}{c}0.7142 \\
(0.2839) \\
{[0.0130]}\end{array}$ \\
\hline $\begin{array}{l}\text { Dummy: } \\
\text { Demand Shock }\end{array}$ & - & $\begin{array}{l}-0.0195 \\
(0.0052) \\
{[0.0003]}\end{array}$ & - & $\begin{array}{l}-0.0055 \\
(0.0033) \\
{[0.0948]}\end{array}$ & $\begin{array}{l}-0.0049 \\
(0.0026) \\
{[0.0636]}\end{array}$ \\
\hline $\begin{array}{l}\text { Dummy: } \\
\text { Supply Shock }\end{array}$ & $\begin{array}{c}0.0090 \\
(0.0112) \\
{[0.4241]}\end{array}$ & $\begin{array}{l}-0.0008 \\
(0.0055) \\
{[0.8886]}\end{array}$ & $\begin{array}{c}0.0120 \\
(0.0036) \\
{[0.0012]}\end{array}$ & $\begin{array}{c}0.0140 \\
(0.0035) \\
{[0.0001]}\end{array}$ & - \\
\hline $\begin{aligned} \text { Notes: } & \\
\text { 1. } & \text { Newey-West } \\
\text { 2. } & \text { Real wage an } \\
& \text { consumer pri } \\
\text { 3. } & \text { The sources } \\
& \text { OECD. } \\
\text { 4. } & \text { Panel A repo } \\
& \text { Gali (2007), a } \\
& \text { shock episod }\end{aligned}$ & $\begin{array}{l}\text { Standard } \\
\text { DP are in lo } \\
\text { dex. } \\
\text { nternationa } \\
\text { stimates wit } \\
\text { Panel B rep } \\
\text { lentified bas }\end{array}$ & $\begin{array}{l}\text { () and prob. } \\
\text { d Band-pas } \\
\text { cial Statistic } \\
\text { mmy variab } \\
\text { timates with } \\
\text { the market }\end{array}$ & $\begin{array}{l}\text { [ ] are in p } \\
\text { d (Baxter-K } \\
\text { e IMF and N } \\
\text { il shock epis } \\
\text { y variables } \\
\text { de oil, as de }\end{array}$ & $\begin{array}{l}\text { eal wage is } \\
\text { denomic Ind } \\
\text { ply shock a } \\
\text { in Append }\end{array}$ & $\begin{array}{l}\text { d on } \\
\text { rs of the } \\
\text { emard and } \\
\text { emand }\end{array}$ \\
\hline
\end{tabular}


Table 2a: OLS Estimates of the Cyclicality of Real Wages - Canada

\begin{tabular}{|c|c|c|c|c|c|}
\hline \multirow{2}{*}{$\begin{array}{l}\text { Dependent variable } \\
\text { Period }\end{array}$} & \multicolumn{5}{|c|}{ (A) Real Wage - detrended } \\
\hline & $\begin{array}{c}(\mathrm{I}) \\
1963 \mathrm{Q} 1- \\
1975 Q 2 \\
\end{array}$ & $\begin{array}{c}(\mathrm{II}) \\
\text { 1975Q3- } \\
\text { 1978Q2 } \\
\end{array}$ & $\begin{array}{c}(\mathrm{III}) \\
\text { 1978Q3- } \\
\text { 1987Q4 }\end{array}$ & $\begin{array}{c}\text { (IV) } \\
\text { 1988Q1- } \\
\text { 1991Q1 } \\
\end{array}$ & $\begin{array}{c}(V) \\
\text { 1991Q2- } \\
2004 Q 4 \\
\end{array}$ \\
\hline Constant & $\begin{array}{l}-0.0008 \\
(0.0022) \\
{[0.7277]}\end{array}$ & $\begin{array}{c}0.0189 \\
(0.0052) \\
{[0.0003]}\end{array}$ & $\begin{array}{c}0.0000 \\
(0.0021) \\
{[0.9713]}\end{array}$ & $\begin{array}{l}-0.0064 \\
(0.0003) \\
{[0.0000]}\end{array}$ & $\begin{array}{c}0.0002 \\
(0.0014) \\
{[0.8805]}\end{array}$ \\
\hline $\begin{array}{l}\text { GDP } \\
\text {-detrended }\end{array}$ & $\begin{array}{l}-0.4785 \\
(0.1728) \\
{[0.0063]}\end{array}$ & $\begin{array}{c}1.4352 \\
(0.6476) \\
{[0.0281]}\end{array}$ & $\begin{array}{l}-0.0575 \\
(0.0707) \\
{[0.4170]}\end{array}$ & $\begin{array}{c}0.0084 \\
(0.0162) \\
{[0.6060]}\end{array}$ & $\begin{array}{l}-0.1949 \\
(0.0492) \\
{[0.0001]}\end{array}$ \\
\hline $\begin{array}{l}\text { Dummy: } \\
\text { Oil shock } \\
\text { (Blanchard-Gali) }\end{array}$ & $\begin{array}{l}-0.0098 \\
(0.0028) \\
{[0.0007]}\end{array}$ & - & $\begin{array}{l}-0.0016 \\
(0.0026) \\
{[0.5465]}\end{array}$ & - & $\begin{array}{c}0.0020 \\
(0.0027) \\
{[0.4681]}\end{array}$ \\
\hline Dependent variable & & & al Wage - & ded & \\
\hline Period & (I) & (II) & (III) & (IV) & $(\mathrm{V})$ \\
\hline Constant & $\begin{array}{l}-0.0017 \\
(0.0020) \\
{[0.3972]}\end{array}$ & $\begin{array}{c}0.0296 \\
(0.0029) \\
{[0.0000]}\end{array}$ & $\begin{array}{c}-0.0001 \\
(.0026) \\
{[0.9688]}\end{array}$ & $\begin{array}{l}-0.0064 \\
(0.0003) \\
{[0.0000]}\end{array}$ & $\begin{array}{c}0.0005 \\
(0.0015) \\
{[0.7341]}\end{array}$ \\
\hline $\begin{array}{l}\text { GDP } \\
\text {-detrended }\end{array}$ & $\begin{array}{l}-0.5956 \\
(0.1808) \\
{[0.0012]}\end{array}$ & $\begin{array}{c}0.7590 \\
(0.3051) \\
{[0.0139]}\end{array}$ & $\begin{array}{l}-0.0599 \\
(0.0732) \\
{[0.4147]}\end{array}$ & $\begin{array}{c}0.0084 \\
(0.0162) \\
{[0.6060]}\end{array}$ & $\begin{array}{l}-0.1781 \\
(0.0475) \\
{[0.0002]}\end{array}$ \\
\hline $\begin{array}{l}\text { Dummy: } \\
\text { Demand Shock }\end{array}$ & - & - & $\begin{array}{l}-0.0013 \\
(0.0031) \\
{[0.6845]}\end{array}$ & - & $\begin{array}{c}0.0009 \\
(0.0027) \\
{[0.7296]}\end{array}$ \\
\hline $\begin{array}{l}\text { Dummy: } \\
\text { Supply Shock }\end{array}$ & $\begin{array}{l}0.0033 \\
(0.0052) \\
{[0.5296]}\end{array}$ & $\begin{array}{l}-0.0215 \\
(0.0023) \\
{[0.0000]}\end{array}$ & $\begin{array}{l}-0.0003 \\
(0.0025) \\
{[0.9139]}\end{array}$ & - & $\begin{array}{c}0.0045 \\
(0.0014) \\
{[0.0021]}\end{array}$ \\
\hline $\begin{aligned} \text { Notes: } & \\
\text { 1. } & \text { Newey-West } \\
\text { 2. } & \text { Real wage an } \\
& \text { price index. } \\
\text { 3. } & \text { The sources a } \\
\text { 4. } & \text { Panel A repor } \\
& \text { (2007), and P } \\
& \text { episodes iden }\end{aligned}$ & $\begin{array}{l}\text { ternational } F \\
\text { imates with }\end{array}$ & $\begin{array}{l}\text { nd prob. v } \\
\text { and-pass fi } \\
\text { Statistics } \\
\text { y variable }\end{array}$ & $\begin{array}{l}\text { are in parer } \\
\text { Faxter-King) } \\
\text { F and Main } \\
\text { ock episod }\end{array}$ & $\begin{array}{l}\text { lage is base } \\
\text { nic Indicator } \\
\text { ified by Blan } \\
\text { and deman } \\
\text { ix B. }\end{array}$ & $\begin{array}{l}\text { consumer } \\
\text { he OECD. } \\
\text { and Gali } \\
\text { ck }\end{array}$ \\
\hline
\end{tabular}


Table 3a: OLS Estimates of the Cyclicality of Real Wages - France

\begin{tabular}{|c|c|c|c|c|c|}
\hline \multirow{2}{*}{$\begin{array}{l}\text { Dependent variable } \\
\text { Period }\end{array}$} & \multicolumn{5}{|c|}{ (A) Real Wage - detrended } \\
\hline & $\begin{array}{c}(\mathrm{I}) \\
\text { 1963Q1- } \\
\text { 1979Q1 }\end{array}$ & $\begin{array}{c}(\mathrm{II}) \\
1979 \mathrm{Q} 2- \\
1983 q 1\end{array}$ & $\begin{array}{c}(I I I) \\
\text { 1983Q2- } \\
\text { 1985Q4 }\end{array}$ & $\begin{array}{c}(I I I) \\
1986 Q 1- \\
1998 Q 4\end{array}$ & $\begin{array}{c}(I V) \\
\text { 1999Q1- } \\
\text { 2004Q4 }\end{array}$ \\
\hline Constant & $\begin{array}{c}0.0004 \\
(0.0018) \\
{[0.8150]}\end{array}$ & $\begin{array}{c}-0.0007 \\
0.0084) \\
{[0.9344]}\end{array}$ & $\begin{array}{c}0.0122 \\
(0.0016) \\
{[0.0000]}\end{array}$ & $\begin{array}{l}-0.0009 \\
(0.0020) \\
{[0.6488]}\end{array}$ & $\begin{array}{c}0.0072 \\
(0.0015) \\
{[0.0001]}\end{array}$ \\
\hline $\begin{array}{l}\text { GDP } \\
\text {-detrended }\end{array}$ & $\begin{array}{l}-0.1985 \\
(0.1427) \\
{[0.1691]}\end{array}$ & $\begin{array}{l}2.5124 \\
(0.9380) \\
{[0.0190]}\end{array}$ & $\begin{array}{l}2.7082 \\
(0.3380) \\
{[0.0000]}\end{array}$ & $\begin{array}{l}-0.1141 \\
(0.1991) \\
{[0.5691]}\end{array}$ & $\begin{array}{l}-0.2279 \\
(0.1251) \\
{[0.0829]}\end{array}$ \\
\hline $\begin{array}{l}\text { Dummy: } \\
\text { Oil shock } \\
\text { (Blanchard-Gali) }\end{array}$ & $\begin{array}{c}0.0061 \\
(0.0044) \\
{[0.1677]}\end{array}$ & $\begin{array}{l}-0.0212 \\
(0.0164) \\
{[0.2201]}\end{array}$ & - & - & $\begin{array}{l}-0.0049 \\
(0.0016) \\
{[0.0049]}\end{array}$ \\
\hline Dependent variable & & & al Wage - & ed & \\
\hline Period & (I) & (II) & (III) & (IV) & $(\mathrm{V})$ \\
\hline Constant & $\begin{array}{l}-0.0008 \\
(0.0021) \\
{[0.6852]}\end{array}$ & $\begin{array}{l}-0.0007 \\
(0.0084) \\
{[0.9344]}\end{array}$ & $\begin{array}{c}0.0129 \\
(0.0015) \\
{[0.0000]}\end{array}$ & $\begin{array}{l}-0.0006 \\
(0.0023) \\
{[0.7803]}\end{array}$ & $\begin{array}{c}0.0019 \\
(0.0020) \\
{[0.3474]}\end{array}$ \\
\hline $\begin{array}{l}\text { GDP } \\
\text {-detrended }\end{array}$ & $\begin{array}{l}-0.1521 \\
(0.1174) \\
{[0.1997]}\end{array}$ & $\begin{array}{l}2.5124 \\
(0.9380) \\
{[0.0190]}\end{array}$ & $\begin{array}{l}2.6603 \\
(0.3676) \\
{[0.0001]}\end{array}$ & $\begin{array}{l}-0.1431 \\
(0.2313) \\
{[0.5390]}\end{array}$ & $\begin{array}{l}-0.2178 \\
(0.1362) \\
{[0.1247]}\end{array}$ \\
\hline $\begin{array}{l}\text { Dummy: } \\
\text { Demand Shock }\end{array}$ & - & $\begin{array}{l}-0.0212 \\
(0.0164) \\
{[0.2201]}\end{array}$ & - & - & $\begin{array}{c}0.0030 \\
(0.0021) \\
{[0.1672]}\end{array}$ \\
\hline $\begin{array}{l}\text { Dummy: } \\
\text { Supply Shock }\end{array}$ & $\begin{array}{c}0.0056 \\
(0.0030) \\
{[0.0710]}\end{array}$ & - & $\begin{array}{l}-0.0089 \\
(0.0021) \\
{[0.0026]}\end{array}$ & $\begin{array}{l}-0.0019 \\
(0.0035) \\
{[0.5837]}\end{array}$ & - \\
\hline $\begin{aligned} \text { Notes: } & \\
\text { 1. } & \text { Newey-West } \\
\text { 2. } & \text { Real wage an } \\
& \text { price index. } \\
\text { 3. } & \text { The sources a } \\
\text { 4. } & \text { Panel A repor } \\
& \text { (2007), and P } \\
& \text { episodes iden }\end{aligned}$ & $\begin{array}{l}\text { Standard err } \\
P \text { are in logs } \\
\text { ternational } F \\
\text { imates with } \\
3 \text { reports est } \\
\text { based on th }\end{array}$ & $\begin{array}{l}\text { and prob. va } \\
\text { and-pass fil } \\
\text { I Statistics o } \\
\text { ny variable f } \\
\text { with dummy } \\
\text { et for crude }\end{array}$ & $\begin{array}{l}\text { are in parer } \\
\text { axter-King) } \\
\text { F and Main } \\
\text { ock episod } \\
\text { es for supp } \\
\text { escribed in }\end{array}$ & $\begin{array}{l}\text { lage is base } \\
\text { nic Indicator } \\
\text { fied by Blan } \\
\text { and deman } \\
\text { ix B. }\end{array}$ & $\begin{array}{l}\text { consumer } \\
\text { the OECD. } \\
\text { d and Gali } \\
\text { ock }\end{array}$ \\
\hline
\end{tabular}


Table 4a: OLS Estimates of the Cyclicality of Real Wages - Germany

\begin{tabular}{|c|c|c|c|c|c|c|}
\hline \multicolumn{2}{|l|}{ Dependent variable } & \multicolumn{5}{|c|}{ (A) Real Wage - detrended } \\
\hline Period & $\begin{array}{c}\text { (I) } \\
\text { 1963Q1- } \\
\text { 1979Q1 }\end{array}$ & $\begin{array}{c}\text { (II) } \\
\text { 1979Q2- } \\
\text { 1983Q4 }\end{array}$ & $\begin{array}{c}(I I I) \\
1984 Q 1- \\
1989 Q 2\end{array}$ & $\begin{array}{c}\text { (IV) } \\
\text { 1989Q3- } \\
\text { 1992Q3 }\end{array}$ & $\begin{array}{c}(V) \\
\text { 1992Q4- } \\
\text { 1998Q4 }\end{array}$ & $\begin{array}{c}(\mathrm{VI}) \\
\text { 1999Q1- } \\
\text { 2004Q4 }\end{array}$ \\
\hline Constant & $\begin{array}{c}0.0030 \\
(0.0033) \\
{[0.3777]}\end{array}$ & $\begin{array}{c}0.0007 \\
(0.0034) \\
{[0.8312]}\end{array}$ & $\begin{array}{l}-0.0100 \\
(0.0036) \\
{[0.0109]}\end{array}$ & $\begin{array}{l}-0.0028 \\
(0.0015) \\
{[0.1002]}\end{array}$ & $\begin{array}{l}-0.0019 \\
(0.0039) \\
{[0.6316]}\end{array}$ & $\begin{array}{l}-0.0018 \\
(0.0017) \\
{[0.3162]}\end{array}$ \\
\hline $\begin{array}{l}\text { GDP } \\
\text {-detrended }\end{array}$ & $\begin{array}{c}0.0081 \\
(0.1492) \\
{[0.9571]}\end{array}$ & $\begin{array}{c}0.5011 \\
(0.1905) \\
{[0.0182]}\end{array}$ & $\begin{array}{l}-1.8571 \\
(0.3037) \\
{[0.0000]}\end{array}$ & $\begin{array}{c}0.2681 \\
(0.0622) \\
{[0.0012]}\end{array}$ & $\begin{array}{l}-0.6179 \\
(0.4863) \\
{[0.2166]}\end{array}$ & $\begin{array}{l}-0.1302 \\
(0.1048) \\
{[0.2277]}\end{array}$ \\
\hline $\begin{array}{l}\text { Dummy: } \\
\text { Oil shock } \\
\text { (Blanchard-Gali) }\end{array}$ & $\begin{array}{l}-0.0021 \\
(0.0075) \\
{[0.7824]}\end{array}$ & $\begin{array}{l}-0.0074 \\
(0.0075) \\
{[0.3369]}\end{array}$ & - & - & - & $\begin{array}{c}0.0051 \\
(0.0022) \\
{[0.0262]}\end{array}$ \\
\hline Dependent variable & & & (B) Real & Wage-det & ended & \\
\hline Period & $(\mathrm{I})$ & (II) & (III) & (IV) & $(\mathrm{V})$ & $(\mathrm{VI})$ \\
\hline Constant & $\begin{array}{c}0.0018 \\
(0.0042) \\
{[0.6655]}\end{array}$ & $\begin{array}{c}0.0007 \\
(0.0034) \\
{[0.8312]}\end{array}$ & $\begin{array}{l}-0.0142 \\
(0.0043) \\
{[0.0038]}\end{array}$ & $\begin{array}{l}-0.0028 \\
(0.0015) \\
{[0.1002]}\end{array}$ & $\begin{array}{l}-0.0012 \\
(0.0045) \\
{[0.7942]}\end{array}$ & $\begin{array}{c}0.0034 \\
(0.0012) \\
{[0.0101]}\end{array}$ \\
\hline $\begin{array}{l}\text { GDP } \\
\text {-detrended }\end{array}$ & $\begin{array}{l}-0.0010 \\
(0.1346) \\
{[0.9943]}\end{array}$ & $\begin{array}{c}0.5011 \\
(0.1905) \\
{[0.0182]}\end{array}$ & $\begin{array}{l}-2.2181 \\
(0.3870) \\
{[0.0000]}\end{array}$ & $\begin{array}{c}0.2681 \\
(0.0622) \\
{[0.0012]}\end{array}$ & $\begin{array}{l}-0.6453 \\
(0.5333) \\
{[0.2391]}\end{array}$ & $\begin{array}{l}-0.1666 \\
(0.1289) \\
{[0.2104]}\end{array}$ \\
\hline $\begin{array}{l}\text { Dummy: } \\
\text { Demand Shock }\end{array}$ & - & $\begin{array}{l}-0.0074 \\
(0.0075) \\
{[0.3369]}\end{array}$ & - & - & - & $\begin{array}{l}-0.0021 \\
(0.0025) \\
{[0.4055]}\end{array}$ \\
\hline $\begin{array}{l}\text { Dummy: } \\
\text { Supply Shock }\end{array}$ & $\begin{array}{c}0.0038 \\
(0.0051) \\
{[0.4661]}\end{array}$ & - & $\begin{array}{c}0.0109 \\
(0.0044) \\
{[0.0218]}\end{array}$ & - & $\begin{array}{l}-0.0048 \\
(0.0040) \\
{[0.2433]}\end{array}$ & - \\
\hline $\begin{aligned} & \text { Notes: } \\
& \text { 1. } \text { Newey-West } \\
& \text { 2. } \text { Real wage an } \\
& \text { based on con } \\
& \text { 3. } \text { The sources } \\
& \text { Indicators of t } \\
& \text { 4. } \text { Panel A repor } \\
& \text { Blanchard an } \\
& \text { supply shock } \\
& \text { described in }\end{aligned}$ & $\begin{array}{l}\text { IC Standar } \\
\text { GDP are in } \\
\text { mer price i } \\
\text { Internatio } \\
\text { OECD. } \\
\text { estimates } \\
\text { tali (2007) }\end{array}$ & $\begin{array}{l}\text { errors ( ) ar } \\
\text { gs, and Ba } \\
\text { lex. } \\
\text { I Financial } \\
\text { th a dummy } \\
\text { nd Panel B }\end{array}$ & $\begin{array}{l}\text { d prob. valu } \\
\text { nd-pass filte } \\
\text { vatistics of } \\
\text { variable for }\end{array}$ & $\begin{array}{l}\text { [ ] ] are in p } \\
\text { ed (Baxter-K } \\
\text { le IMF and } \\
\text { oil shock ep } \\
\text { lates with di } \\
\text { oased on th }\end{array}$ & $\begin{array}{l}\text { arenthesis. } \\
\text { ing). Real } \\
\text { lain Econon } \\
\text { modes ident } \\
\text { mmy variab }\end{array}$ & $\begin{array}{l}\text { d by } \\
\text { for } \\
\text { de oil, as }\end{array}$ \\
\hline
\end{tabular}


Table 5a: OLS Estimates of the Cyclicality of Real Wages - United Kingdom

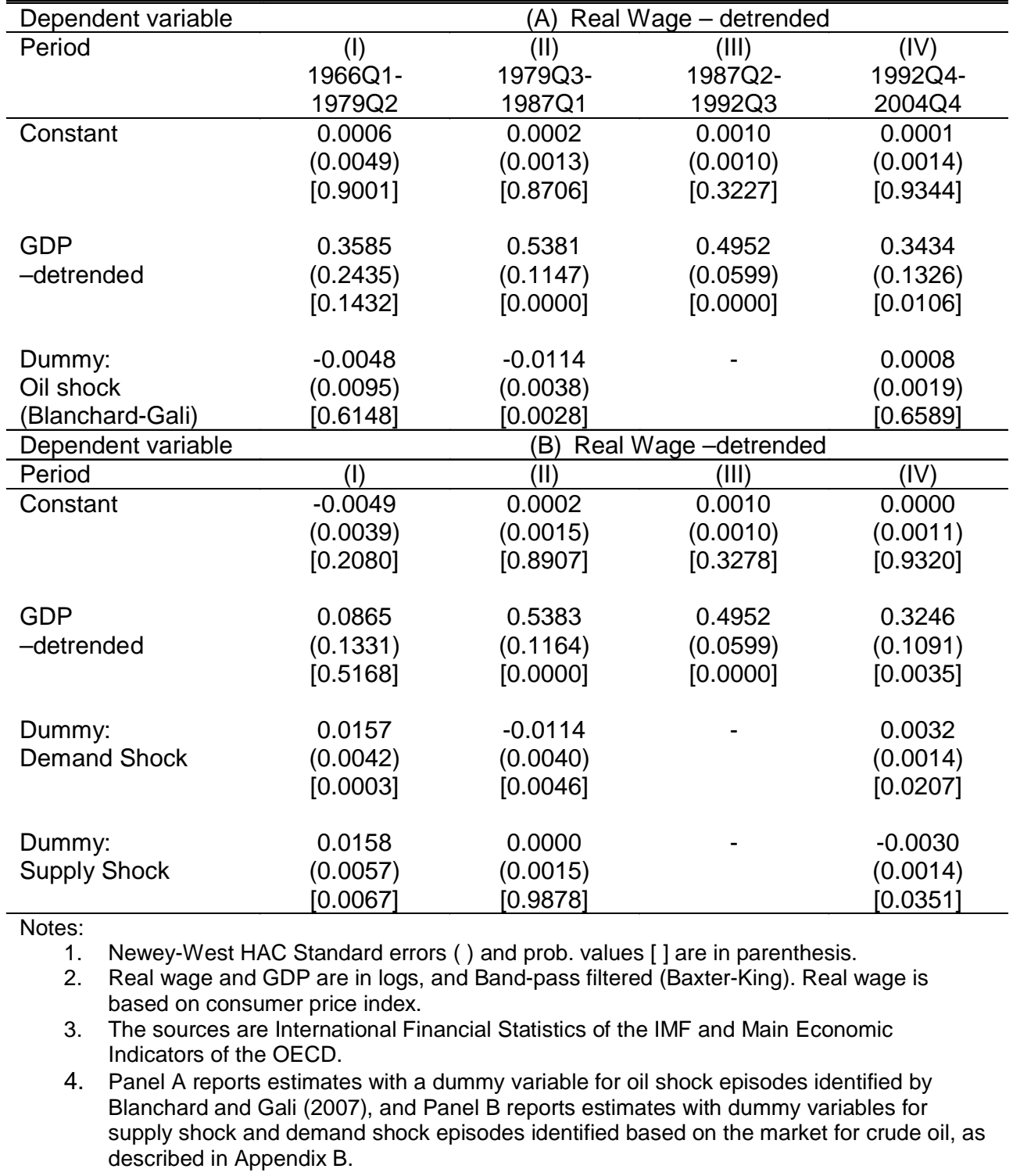


Table 6a: OLS Estimates of the Cyclicality of Real Wages - United States

\begin{tabular}{|c|c|c|c|}
\hline Dependent variable & \multicolumn{3}{|c|}{ (A) Real Wage - detrended } \\
\hline Period & $\begin{array}{c}(\mathrm{I}) \\
\text { 1960Q1- } \\
1978 Q 2\end{array}$ & $\begin{array}{c}(I I) \\
1978 q 3- \\
1981 Q 4\end{array}$ & $\begin{array}{c}\text { (III) } \\
\text { 1982Q1- } \\
\text { 2004Q4 }\end{array}$ \\
\hline Constant & $\begin{array}{c}0.0024 \\
(0.0018) \\
{[0.1911]}\end{array}$ & $\begin{array}{l}-0.0148 \\
(0.0031) \\
{[0.0006]}\end{array}$ & $\begin{array}{l}-0.0008 \\
(0.0010) \\
{[0.4391]}\end{array}$ \\
\hline $\begin{array}{l}\text { GDP } \\
\text {-detrended }\end{array}$ & $\begin{array}{l}0.5501 \\
(0.1190) \\
{[0.0000]}\end{array}$ & $\begin{array}{l}1.6302 \\
(0.1931) \\
{[0.0000]}\end{array}$ & $\begin{array}{c}0.0131 \\
(0.0602) \\
{[0.8288]}\end{array}$ \\
\hline $\begin{array}{l}\text { Dummy: } \\
\text { Oil shock } \\
\text { (Blanchard-Gali) }\end{array}$ & $\begin{array}{l}-0.0118 \\
(0.0045) \\
{[0.0107]}\end{array}$ & $\begin{array}{l}-0.0138 \\
(0.0042) \\
{[0.0074]}\end{array}$ & $\begin{array}{c}0.0053 \\
(0.0021) \\
{[0.0144]}\end{array}$ \\
\hline Dependent variable & \multicolumn{3}{|c|}{ (B) Real Wage -detrended } \\
\hline Period & $(\mathrm{l})$ & (II) & (III) \\
\hline Constant & $\begin{array}{c}0.0010 \\
(0.0016) \\
{[0.5348]}\end{array}$ & $\begin{array}{l}-0.0156 \\
(0.0024) \\
{[0.0001]}\end{array}$ & $\begin{array}{l}-0.0004 \\
(0.0010) \\
{[0.6864]}\end{array}$ \\
\hline $\begin{array}{l}\text { GDP } \\
\text {-detrended }\end{array}$ & $\begin{array}{c}0.4821 \\
(0.1105) \\
{[0.0000]}\end{array}$ & $\begin{array}{l}1.1302 \\
(0.2350) \\
{[0.0007]}\end{array}$ & $\begin{array}{c}0.0253 \\
(0.0543) \\
{[0.6422]}\end{array}$ \\
\hline $\begin{array}{l}\text { Dummy: } \\
\text { Demand Shock }\end{array}$ & - & $\begin{array}{l}-0.0072 \\
(0.0035) \\
{[0.0665]}\end{array}$ & $\begin{array}{c}0.0012 \\
(0.0028) \\
{[0.6836]}\end{array}$ \\
\hline $\begin{array}{l}\text { Dummy: } \\
\text { Supply Shock }\end{array}$ & $\begin{array}{c}0.0045 \\
(0.0045) \\
{[0.3225]}\end{array}$ & $\begin{array}{c}0.0155 \\
(0.0068) \\
{[0.0465]}\end{array}$ & $\begin{array}{c}0.0067 \\
(0.0026) \\
{[0.0119]}\end{array}$ \\
\hline
\end{tabular}

Notes:

1. Newey-West HAC Standard errors ( ) and prob. values [ ] are in parenthesis.

2. Real wage and GDP are in logs, and Band-pass filtered (Baxter-King). Real wage is based on consumer price index.

3. The sources are International Financial Statistics of the IMF and Main Economic Indicators of the OECD.

4. Panel A reports estimates with a dummy variable for oil shock episodes identified by Blanchard and Gali (2007), and Panel B reports estimates with dummy variables for supply shock and demand shock episodes identified based on the market for crude oil, as described in Appendix B. 